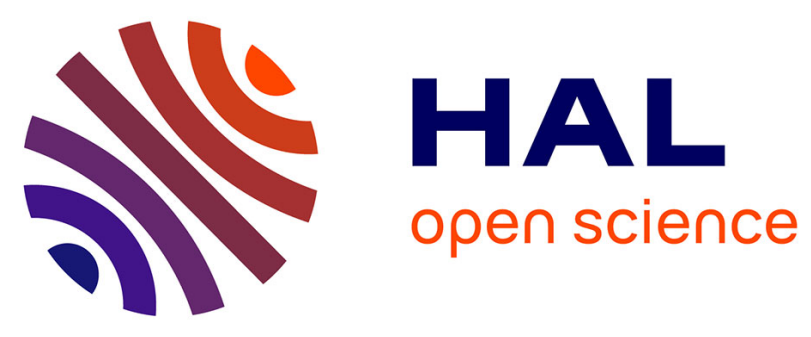

\title{
Holocene hydrological changes in SE Iran, a key region between Indian Summer Monsoon and Mediterranean winter precipitation zones, as revealed from a lacustrine sequence from Lake Hamoun
}

Mohammad Ali Hamzeh, Mohammad Hosein Mahmudy Gharaie, Hamid Alizadeh Ketek Lahijani, Morteza Djamali, Reza Moussavi Harami, Abdolmajid Naderi Beni

\section{- To cite this version:}

Mohammad Ali Hamzeh, Mohammad Hosein Mahmudy Gharaie, Hamid Alizadeh Ketek Lahijani, Morteza Djamali, Reza Moussavi Harami, et al.. Holocene hydrological changes in SE Iran, a key region between Indian Summer Monsoon and Mediterranean winter precipitation zones, as revealed from a lacustrine sequence from Lake Hamoun. Quaternary International, 2016, 408 (A, SI), pp.25-39. 10.1016/j.quaint.2015.11.011 . hal-01444622

\author{
HAL Id: hal-01444622 \\ https://hal.science/hal-01444622
}

Submitted on 21 Feb 2022

HAL is a multi-disciplinary open access archive for the deposit and dissemination of scientific research documents, whether they are published or not. The documents may come from teaching and research institutions in France or abroad, or from public or private research centers.
L'archive ouverte pluridisciplinaire HAL, est destinée au dépôt et à la diffusion de documents scientifiques de niveau recherche, publiés ou non, émanant des établissements d'enseignement et de recherche français ou étrangers, des laboratoires publics ou privés. 


\title{
Holocene hydrological changes in SE Iran, a key region between Indian Summer Monsoon and Mediterranean winter precipitation zones, as revealed from a lacustrine sequence from Lake Hamoun
}

\author{
Mohammad Ali Hamzeh a, b, Mohammad Hosein Mahmudy Gharaie a, *, \\ Hamid Alizadeh Ketek Lahijani ${ }^{\text {b }}$, Morteza Djamali ${ }^{\mathrm{c}}$, Reza Moussavi Harami ${ }^{\text {a }}$, \\ Abdolmajid Naderi Beni ${ }^{\mathrm{b}}$

\footnotetext{
a Department of Geology, Faculty of Science, Ferdowsi University of Mashhad, Mashhad, Iran

${ }^{\mathrm{b}}$ Iranian National Institute for Oceanography and Atmospheric Science (INIOAS), Tehran, Iran

' Institut Méditerranéen de Biodiversité et d'Ecologie marine et continentale (IMBE), UMR CNRS 7263/IRD 237, Aix- Marseille Université, Technopôle de
} \\ l'Environnement Arbois-Méditerranée, BP 80, F-13545, Aix-en-Provence cedex 04, France
}

\section{A R T I C L E I N F O}

Article history:

Available online $\mathrm{xxx}$

Keywords:

Sistan

Sedimentology

Palaeoenvironment

Palaeostorms

\begin{abstract}
A B S T R A C T
Core sediments from the dry lake bed of Hamoun were subdivided into 3 main sedimentary units using a multi-proxy approach (e.g. petrography, grain size analysis, total organic matter $\%$ and $\mathrm{CaCO}_{3} \%$ determination) to reconstruct the palaeoenvironment of the Sistan Basin (SE Iran) as a transition zone between the monsoon summer precipitation zone of south Asia and the Mediterranean winter precipitation zone of the Iranian plateau during the Holocene. Data revealed that during the late-glacial to early Holocene, the lake and its catchment area, western Hindu Kush, were under a more prominent influence of the Indian Ocean monsoon and formed a moist and productive environment with less wind action, as shown by the provenance of high organic matter lacustrine sediments together with the lack of an aeolian fraction. Due to southward migration of the Inter Tropical Convergence Zone during the mid Holocene, arid climate manifested by an interplay of seasonal aeolian and fluvial deposition became dominant. These conditions were due to reinforcement of subtropical anticyclones on the Iranian plateau. The presence of green to brownish green moderate organic matter lacustrine sediments showed that during the late Holocene, Mediterranean-type winter precipitation dominated in the area. During the initial part of this period, the Shahr-i Sukhteh civilization was close to the lake. The environment was relatively similar with that of today. Some palaeostorms can also be detected during this time interval, shown by occurrences of high aeolian inputs in the basin.
\end{abstract}

\section{Introduction}

Several components of atmospheric circulation patterns, including the Mid Latitude Westerlies (MLW) and the Indian Summer Monsoon (ISM), govern the climatic conditions of SW Asia. The relative influence of the systems is dependent on variations in the mean latitudinal position of the Inter Tropical Convergence Zone (ITCZ) in tropical and also extratropical regions on a variety of

\footnotetext{
* Corresponding author.

E-mail addresses: mahamzeh1183@gmail.com (M.A. Hamzeh), mhmgharaie@ um.ac.ir (M.H. Mahmudy Gharaie), lahijani@inio.ac.ir (H. Alizadeh Ketek Lahijani), morteza.djamali@imbe.fr (M. Djamali), moussavi@um.ac.ir (R. Moussavi Harami) naderi@inio.ac.ir (A. Naderi Beni).
}

time scales, ranging from monthly to millennial (Fleitmann et al., 2007). During the Holocene, the ITCZ translocations have been accompanied by significant variations in the hydrological cycle in different parts of Asia and Africa (Gasse, 2000; Fleitmann et al., 2003; Dykoski et al., 2005). In order to understand the past changes in relative contribution of MLW vs ISM in the spatiotemporal distribution and amount of precipitation in western and Central Asia (CA), many palaeoenvironmental investigations have been conducted using different proxies in eastern Mediterranean, Turkey, western Iran, Arabian Sea and Arabian peninsula, Indian sub-continent, CA, semi-arid western Himalaya and Karakoram, and the Tibetan plateau (Fig. 1). However, chronological uncertainties, low resolution of studies, and spatio-temporal gaps in available records had made it difficult to establish a dense and 


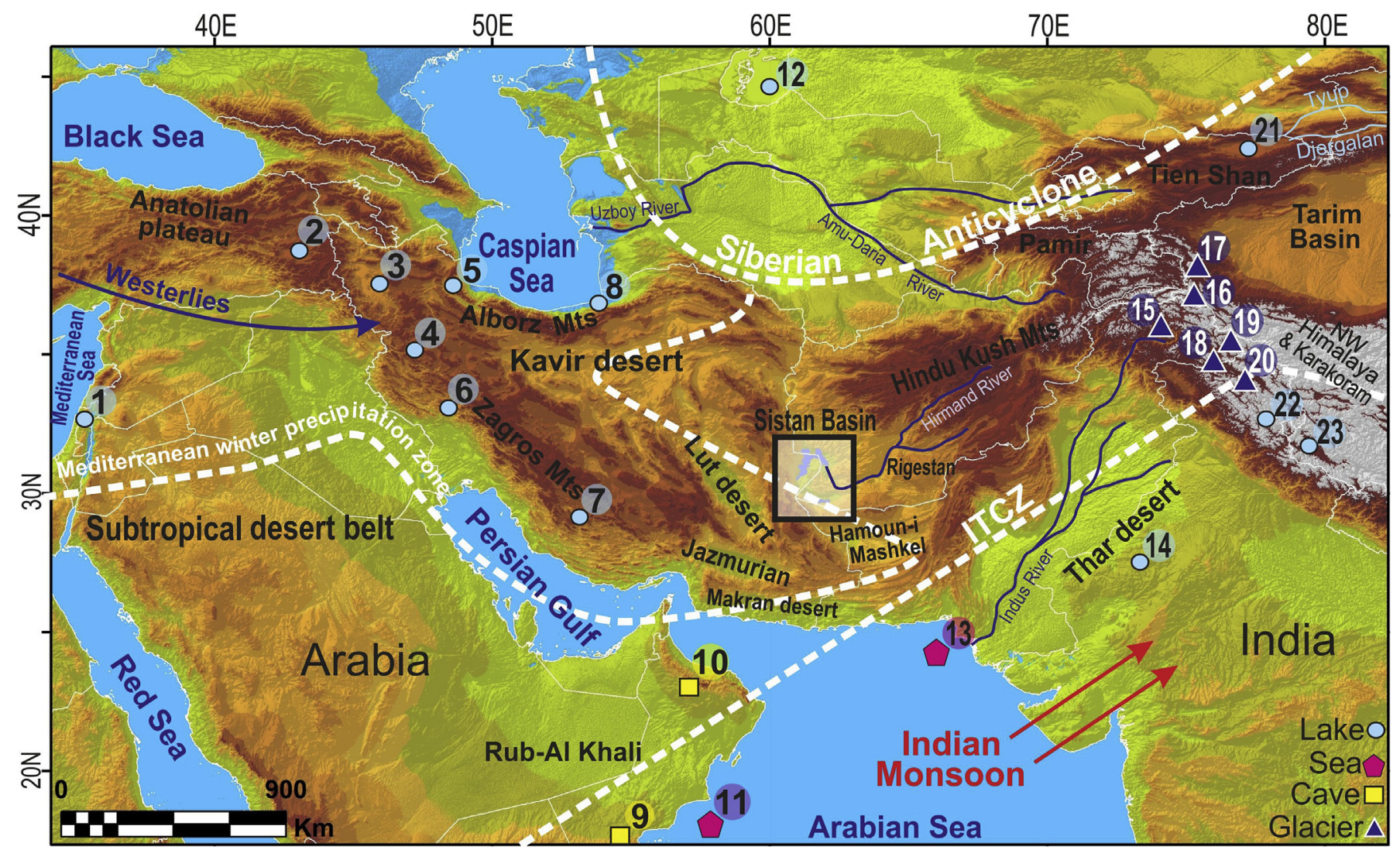

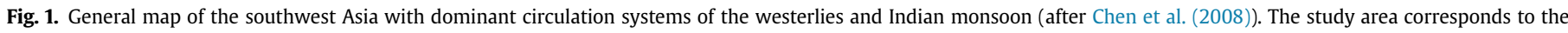

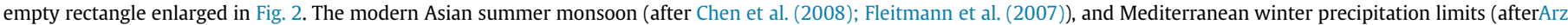

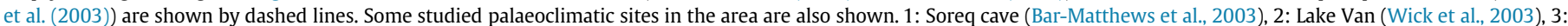

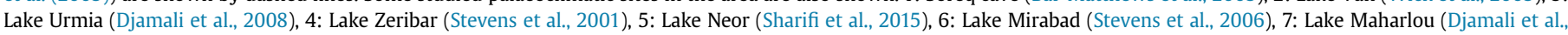

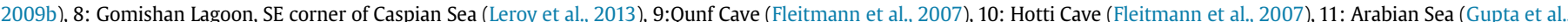

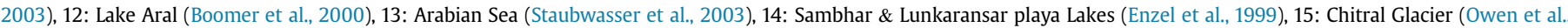

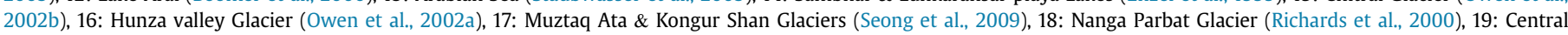

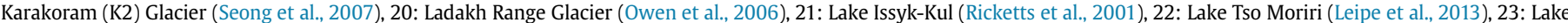
Bangong Co (Van Campo et al., 1996).

uniform network of well-resolved and continuous palaeoclimate records in the area. Furthermore, the Holocene palaeoclimatological studies in Iran are infrequent, sparse and are focused on the Zagros Mountains (Kehl, 2009). The investigations are mainly based on palynology, stable isotope geochemistry and palaeolimnological indicators in lakes of Urmia (Bottema, 1986; Djamali et al., 2008), Zeribar (Van Zeist and Wright, 1963; Stevens et al., 2001; Wasylikowa et al., 2006), Neor (Sharifi et al., 2015), Mirabad (Griffiths et al., 2001; Stevens et al., 2006; Lambert, 2010), Almalou (Djamali et al., 2009a) and Maharlou (Djamali et al., 2009b). In this regard, one of the most important spatial gaps of the western Asia is located in eastern Iran, western Pakistan, and southern Afghanistan where few palaeoclimatic studies have been conducted (Fig. 1). This is mainly because of logistical inaccessibility and political instability that make research efforts a challenging activity in this area.

Lake Hamoun is a remarkable environment to study hydroclimatic changes in both Sistan Basin (eastern Iran - southwestern Afghanistan) and its vast watershed area that extends into the Hindu Kush Mountains (Fig. 1). The area is one of the driest regions in the world whose sparse water resources and fragile ecosystems are very sensitive to climate change. In moist periods, fluviolacustrine and palustrine conditions are dominant while in dry periods, aeolian activities prevail. Hence, variations of fluviolacustrine and aeolian deposits in sedimentary successions could be a useful tool to evaluate palaeoenvironmental conditions over the Sistan Basin during the Holocene. Moreover, potential records of the past climatic changes in the lake sediments could help us to understand human-environment interaction when the results are compared with historical and archeological data.

In spite of the importance of eastern Iran in reconstruction of west Asia's climatological history, there is almost no available palaeoenvironmental and palaeoclimatic data from this historical site. Previous studies on aeolian records in this area were mainly focused on modern dust storms, aeolian sands and sand dunes (Rashki and Kaskaoutis, 2012; Rashki et al., 2013). Studies on disentangling different depositional components of the lake sediments (aeolian versus fluvio-lacustrine) and their palaeoclimatic implications are absent.

Sediments of Lake Hamoun provide a great opportunity to differentiate hydroclimatic phases of the Sistan Basin as the most available proxy for palaeoclimatological investigations. This investigation aims to reconstruct the Holocene environmental changes of Lake Hamoun based on basic sedimentological studies and a rough radiocarbon chronology and chronostratigraphy.

\section{Study area}

\subsection{Geology}

The Sistan Basin is a tectonically closed basin in western part of Afghan Block (close to the Lut Block in Iran) whose formation dates 


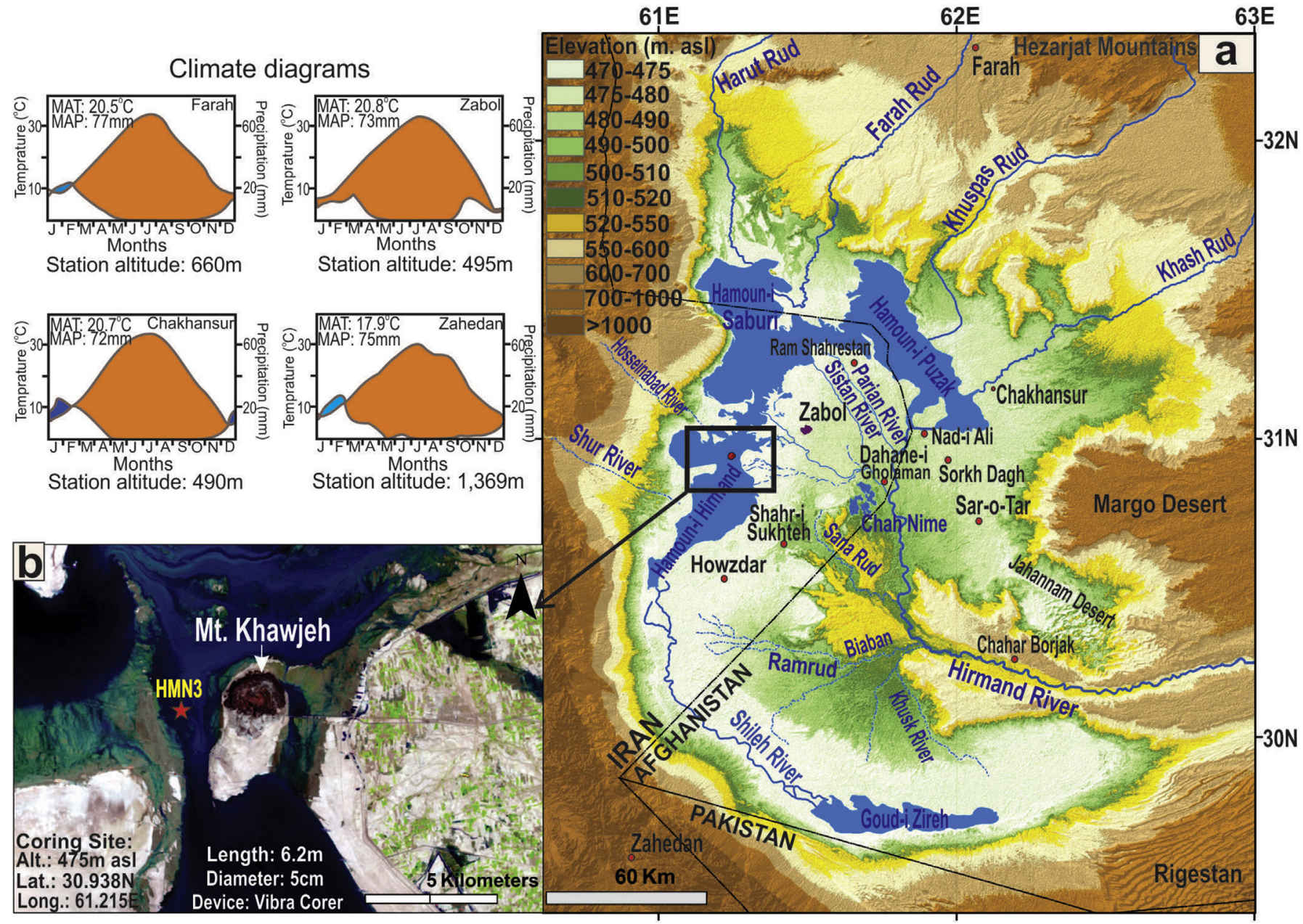

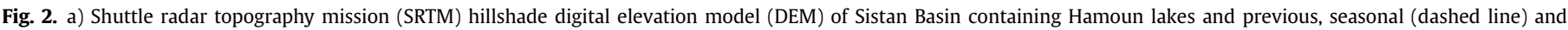

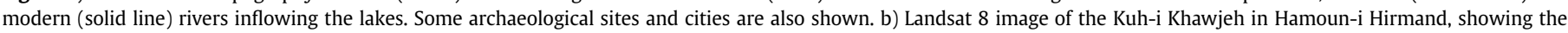

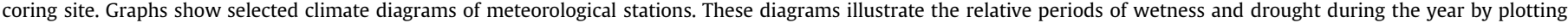

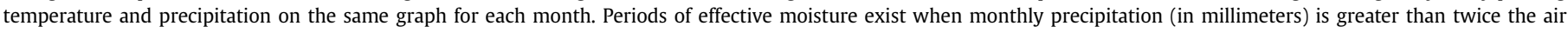
temperature in degrees Celsius (after Whitney (2007)).

to the Palaeogene after the collision of several Gondwanaland plates and microplates (Krumsiek, 1980). During the Neogene, subsidence led to the formation of this basin (Schieber et al., 2007). The continued subsidence along the active Harirud fault system caused the formation of the Sistan depression during the Neogene and Quaternary. The 121 m-high Kuh-i Khawjeh (Mount Khawjeh), a $7.3 \pm 0.2$ Ma basaltic lava flow (Jux and Kempf, 1983), is the most considerable geomorphological feature in Lake Hamoun (Fig. 2b) (Jux and Kempf, 1983). The entire study area is covered by finegrained silt and clay, mostly lacustrine sediments (Hafezi Moghaddas, 2012).

\subsection{Climate}

The Sistan Basin is located within the Asian part of the desert belt in the temperate subtropical zone of the Northern Hemisphere. The area is situated between $29^{\circ}$ and $32^{\circ} \mathrm{N}$ (Fig. 1a) on the north edge of the subtropical dry zone. This arid climatic zone is the result of worldwide circulation patterns of air that create semipermanent high pressure cells in the general region of the tropics. At the basin and its catchment area, western Hindu Kush, a winter precipitation regime under the westerlies is dominant (Fig. 1). However, it is believed that during the early to mid
Holocene, a more northern position of ITCZ caused monsooninduced summer precipitation in northwestern Himalaya, Karakoram and Hindu Kush (Owen et al., 2005; Owen, 2009) and also in the Sistan Basin (Whitney, 2007).

Fig. 2 shows some climate diagrams constructed from the meteorological data (Whitney, 2007) for some selected stations in Sistan Basin. Mean annual precipitation in Zabol, the most populated city of Iranian Sistan on the border with Afghanistan, is $64 \mathrm{~mm}$, mostly falling between December and March. MLW lose the majority of their moisture over the high Zagros Mountains before reaching the Sistan Basin. On the other hand, the Sulaiman Mountains and the Makran Mountains serve as a southern barrier to the moisture-bearing monsoons. Occasionally, monsoons can enter the high mountainous areas of eastern Afghanistan and cause summer floods (Sivall, 1977). Some of this precipitation may enter the Sistan Basin from Arghandab, the eastern tributary of the Hirmand River.

Evaporation rate in Sistan Basin is more than $4000 \mathrm{~mm} \mathrm{y}^{-1}$, mostly in June-July. Since the beginning of the 21st century, the area has experienced a relatively severe drought period. According to Barlow et al. (2002), the ENSO (El Niño-Southern Oscillation) cold phase and unusually warm ocean waters in the western Pacific seem to be responsible for the drought by causing negative 
anomalies over central Afghanistan and positive anomalies in the Indian Ocean.

The most frequent dust storm events in southwestern Asia are related to the Sistan Basin, where the city of Zabol has experienced the dustiest days in the world (Middleton, 1976). The high frequency of dust and sand storms over the region is caused by the fact that loose soils of the Hamoun Lake are blown away by the strong persistent "winds of 120 days". In late spring and throughout summer and early autumn, the Sistan Basin is dominated by northerly winds. The winds are related to the north-south pressure gradient between a persistent cold high-pressure system over the Hindu Kush Mountains in northern Afghanistan and a summertime thermal low-pressure system over the desert lands of the Sistan Basin as a result of sustained surface warming (Alizadeh-Choobari et al., 2014). This condition leads to high speed surface winds. For example, McMahon (1906) recorded a wind speed of $39.3 \mathrm{~m} \mathrm{~s}^{-1}$ for a $16 \mathrm{~h}$ period (with the maximum wind speed of $53.6 \mathrm{~m} \mathrm{~s}^{-1}$ ) over the Sistan Basin in 1905.

\subsection{Basin hydrology}

The Sistan depression, containing four shallow basins, lies on the Iran-Afghanistan border. It receives the discharge of four rivers: the Hirmand River, Khash Rud, Farah Rud and Harut Rud (Fig. 2a). These rivers receive their water from seasonal precipitation, brought mostly by MLW over the Hindu Kush Mountains (Smith, 1974). The main river, Hirmand River, is $1400 \mathrm{~km}$ long and drains $170,000 \mathrm{~km}^{2}$. Based on stream flow calculations in Khwabgah station (on the border between Iran and Afghanistan), mean annual discharge of Hirmand River during the last eight decades has been up to $346 \mathrm{~m}^{3} \mathrm{~s}^{-1}$ (in water year 1976), with the maximum in April-May and minimum in July-February (Williams-Sether, 2008). During the water year of 1976, maximum monthly discharge of Hirmand River was $1240 \mathrm{~m}^{3} \mathrm{~s}^{-1}$ in May. The entire catchment area of four rivers comprises $340,000 \mathrm{~km}^{2}$, which is $51.8 \%$ of the surface of Afghanistan (Jux and Kempf, 1983). The rivers finally enter Lake Hamoun containing three sub-basins of Hamoun-i Puzak $\left(480 \mathrm{~km}^{2}\right)$, Hamoun-i Saburi $\left(800 \mathrm{~km}^{2}\right)$ and the Hamoun-i Hirmand $\left(650 \mathrm{~km}^{2}\right)$ with a mean water surface at about $472 \mathrm{~m}$ a.s.l (Whitney, 2007). During flood periods (almost in spring time), Lake Hamoun overflows into the fourth depression of Goud-i Zireh (465 m a.s.l.) in Afghanistan via the Shileh River.

\subsection{Historical civilizations}

Hirmand River is the only perennial desert river between the Indus and Tigris-Euphrates Rivers that has provided water source for development of various civilizations in the Sistan Basin since more than $6 \mathrm{ka}$. The position of archeological ruins over a large area in the Hirmand Delta and around the lakes shows the association of the settlements with the life-bearing Hirmand River. Archeological excavations at Shahr-i Sukhteh (Burnt City) (Tosi, 1983), located at the edge of the Hamoun-i Hirmand (Fig. 2a), revealed that human societies developed rudimentary irrigation systems and lived in proto-urban settings by $5.2 \mathrm{ka}$, several centuries before the great Harappan cities of the Indus Valley civilization appeared to the east (Tosi, 1983).

According to historical reports (Goldsmid, 1875; Pumpelly, 1905; Hedin, 1910; Annandale and Prashad, 1919) several intense droughts have occurred during the last two centuries $(1870,1903$, 1920 s, 1970 and 1994), causing migration of some native people from the Sistan Basin to other parts of Iran. A severe drought happened in $835 \mathrm{AD}$ that was mentioned in older reports such as Tarikh-i Sistan (Author, 1935). According to Author (1935), the population was struggling with the misery caused by an unusual lack of water in the Sistan Basin.

\section{Materials and methods}

\subsection{Coring}

The selected site for coring is located at the middle part of the lake in Hamoun-i Hirmand, about $2 \mathrm{~km}$ west of Kuh-i Khawjeh (Fig. 2b). This area received water from Hirmand tributaries from south since prehistoric times until about 2000 BP (Whitney, 2007). Since 2000 BP and from the Sassanid Dynasty and Islamic period to present (except a gap during Saffavid) the area received water from the north (Whitney, 2007). A $6.2 \mathrm{~m}$ long core (hereafter called HMN3) with a $5 \mathrm{~cm}$ diameter was recovered using a vibrocorer in September 2013 when the lake was desiccated after a short period of inundation in spring. The water table at the coring time was $3.5 \mathrm{~m}$ below the surface.

\subsection{Core analysis}

After cores arrival in the lab, a MS2C Bartington magnetic susceptibility meter was used for whole-core Magnetic Susceptibility (MS) measurements at $1 \mathrm{~cm}$ increments. Then, the cores were split, visually described, photographed, and subsampled. From the studied core, we collected 66 samples for grain-size analysis, grain morphoscopy, determination of Total Organic Matter (TOM) content, carbonate content and the fraction of shell fragments. The sampling intervals were defined based on lithological and MS variations. Moreover, 130 samples were taken for palynological study. In total, 15 samples were examined for petrography. Grainsize analysis of samples was performed using a FRITSCH laser particle sizer, which has a measurement range of $0.01-1000 \mu \mathrm{m}$ in 62 channels. The samples were pre-treated using the conventional chemical procedures as outlined by Konert and Vandenberghe (1997). Before the grain-size measurement, $10 \mathrm{ml}$ of $0.05 \mathrm{M}$ $\left(\mathrm{NaPO}_{3}\right)_{6}$ was added to the solution to facilitate deflocculating and the dispersion of sediment particles. Some samples were selected for repeated measurement to confirm the reliability of the grain size analyses. The results showed less than $5 \%$ of relative standard deviation in repeated measurements. TOM and calcium carbonate were determined using loss on ignition method (Heiri et al., 2001). Sediment color was determined using Munsell soil color charts (Charts, 2000). Optical petrography of sediments was conducted using Nikon LV50i POL and microscopic pictures were taken using a digital camera installed on the device. All analyses were performed in the marine geology laboratory, Iranian National Institute for Oceanography and Atmospheric Science (INIOAS).

\section{Results and interpretation}

\subsection{Dating}

The sediments of core HMN3 are mostly composed of calcareous mud and aeolian sand with low organic matter. High carbonate content could influence the radiocarbon age data of gastropod shells. The high carbonate content is mainly related to PlioPleistocene deposits that may contain old organic matter content (e.g. charcoals), as well.

Two bulk samples were selected from the lower half of the core for radiocarbon dating (Table 1). The calibrated dates suggest late-glacial age. However, these ages show an 'age inversion' which is difficult to explain. According to the position of samples, it seems the inversion is due to concentration of reworked organic matter 
Table 1

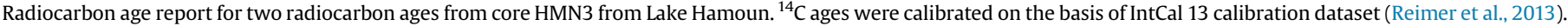

\begin{tabular}{|c|c|c|c|c|c|c|}
\hline Sample number & Lab code & Depth $(\mathrm{cm})$ & ${ }^{14} \mathrm{C}$ age (yr BP) & Calibrated age (cal BP) & Age-ranges (cal BP) & Material dated \\
\hline HMN-3535 & Poz-61286 & $535-536$ & $13,730 \pm 70$ & $16,592 \pm 284$ & $16,312-16,880$ & Mud \\
\hline HMN-3615 & Poz-61477 & $615-616$ & $11,420 \pm 60$ & $13,264 \pm 138$ & $13,126-13,403$ & Mud \\
\hline
\end{tabular}

deposited after an erosional event near the upper sample (Fig. 3). Thus, the older sample was excluded from age data (Fig. 3).

In this paper, we are cautious about giving a detailed chronology and we try to attribute a very rough chronology to our sedimentary units based on the radiocarbon dating. To rectify this situation, we have tried to correlate our results with other regional palaeohydrological and palaeoclimatic records.

\subsection{Core description}

The core lithology generally consists of clayey silt, silt and sandy silt layers. Based on basic sedimentological data, MS and sediment color as well as fossil content, we have recognized three main units, A, B and C. The brief description of the units is shown in Fig. 3. According to Fig. 3, some abrupt changes in MS and mean grain size values can be distinguished, which could be related to changes in sediment transportation/deposition conditions.

Unit A. Unit A with a thickness of $2 \mathrm{~m}$, is characterized by greenish grey to grey color, high TOM $(2.3 \%-12.2 \%$, average: $8.2 \%)$ and $\mathrm{CaCO}_{3}$ content $(17.0 \%-34.1 \%$, average: $26.3 \%)$ and suggests a palustrine (marsh) environment. However, in the upper $30 \mathrm{~cm}$ of the unit, mean TOM (6.5\%) and $\mathrm{CaCO}_{3}$ content (23.9\%) decreases. The clay portion varies from $11.6 \%$ to $41.2 \%$ and has a mean value of $24.0 \%$. Silt content fluctuates between $58.2 \%$ and $76.5 \%$, with an average of $68.1 \%$. By contrast, sand has a low average content of $7.9 \%$, although it oscillates between $0.6 \%$ and $27.9 \%$. Relatively high sand fraction is found at the depth of $560 \mathrm{~cm}$. Low MS values for both sub-units A1 $\left(3.1-4.6 \times 10^{-4}\right.$; mean: $\left.3.7 \times 10^{-4}\right)$ and $\mathrm{A} 2$ $\left(4.9-6.3 \times 10^{-4}\right.$; mean: $\left.5.6 \times 10^{-4}\right)$ mean that in this period lower amounts of detrital grains were carried into the basin. In a core about $2 \mathrm{~km}$ west of core HMN3 (not studied in detail), the correlated layer is pale brown with much lesser TOM\% and higher amounts of gypsum. This confirms that the organic-rich unit A is limited to the eastern part of the basin and laterally changes into a flood plain facies.

Unit $B$. The sub-unit B1 (thickness: $1.5 \mathrm{~m}$ ) is characterized by lamination of pale brown aeolian sand and fluvio-lacustrine silt. The clay fraction along the sub-unit B1 varies between $7.7 \%$ and $24.0 \%$, with an average of $16.2 \%$, while the silt content fluctuates between $36.6 \%$ and $74.5 \%$, with an average of $60 \%$, the lowest silt content of the whole core. The TOM and calcium carbonate content in this unit are $4.9 \%$ and $23.0 \%$, respectively. The upper part of Unit B (sub-unit B2) shows evidence of a more productive environment such as plant remains, gastropod, and ostracod shells.

Unit C. Light brownish green to light green of clayey silts of sub-unit C1 (depth: 205-250 cm) seems to be evidence of an intermittent or permanent shallow lake that allowed oxidization of the bottom sediments. Moving upward, the sand fraction increases gradually to reach to aeolian sands of sub-unit C2. In this thin layer (10 $\mathrm{cm}$ thick), sand percentage reaches its maximum mean value of $62.2 \%$, containing reworked shell fragments. Generally, the sub-unit C3 (depth: 0-190 cm) is distinguished by its relatively fine sediments. However, the sand fraction increases dramatically in three different horizons $(70 \mathrm{~cm}, 120 \mathrm{~cm}$ and $160 \mathrm{~cm}$ ) which is coeval with higher MS values. Mean values of sand, silt and clay content in this unit (except above mentioned horizons) are 11.2,
68.7 and 20.1, respectively. Sub-unit C3 contains frequent plant remains, charophytes, shells, and peat/gyttja. The characteristics of sub-unit C3 along with the light grey to light greenish grey color of the sediments indicate an intermittent to perennial lake that had oxygen deficient conditions at the bottom. At 35-50 cm depth, charcoal appears in large amounts. Significant presence of root traces in the upper parts suggests that a palustrine environment replaced the former lacustrine environment towards the top of the core, allowing development of pedogenic features.

\subsection{Sediment partitioning based on grain size distribution}

Sediment grain size is a useful proxy that has been widely used in palaeoenvironmental investigations. Grain size frequency curves are often implemented to distinguish different sediment components deposited in lake environments (Jiang and Ding, 2010; An et al., 2012). Deciphering aeolian records from lacustrine sediments (Sun et al., 2002; Jiang and Ding, 2010; An et al., 2011, 2012) could provide direct information on the variation of dust storms due to palaeo-droughts and changes in wind direction and intensity.

We compared grain size distribution diagrams of the sediment samples with typical diagrams of dust in the Sistan Basin as well as modern dust, dust storm, loess, lacustrine and fluvial sediments from other parts of the world. Fig. 4 shows the polymodal grain-size frequency distribution curves for samples from different units. Here, we have used the average values of similar grain-size frequency to draw the curves. According to Fig. 4, two types of frequency distribution curves are observed. The Type- 1 curve has two or three Modal Peaks (MP), with the highest peak (MP1) about 20-30 $\mu \mathrm{m}$ and lower peak (MP2) between 1 and $4 \mu \mathrm{m}$. The third and the lowest peak (MP3) is between 200 and $300 \mu \mathrm{m}$ (Fig. 4a, e, $\mathrm{g})$. However, the relative amplitude of peaks in a particular diagram differs from other diagrams.

Compared to Type- 1 curves, the curve of Type- 2 shows higher values for MP1 ( $50-120 \mu \mathrm{m})$ while other peaks are the same as in Type-1 (Fig. 4b, c, d, f, h). The areas of overlapping in the two types of curves could correspond to similar sedimentary components.

Based on Rashki et al. (2013), the median grain size $\left(d_{0.5}\right)$ distributions of deposited dust in the Sistan Basin ranges between $\sim 10$ and $118 \mu \mathrm{m}$. According to the results of this investigation and comparison with the findings of Sun et al. (2002), the sediments of Lake Hamoun could be classified based on sources and depositional environment.

For sub-unit A1, two MPs of 28 and $3 \mu \mathrm{m}$ show a typical lacustrine environment with two suspension components relating to two fluvial events. In sub-unit A2, however, MP1 represents typical aeolian sand. Other modal peaks are similar to that of sub-unit A1. Sub-unit B1 demonstrates aeolian sediments (MP1: $48 \mu \mathrm{m}$ ), comparable with current windblown dust in the Sistan Basin (Rashki and Kaskaoutis, 2012) as well as suspended load of fluviolacustrine sediments (MP2: $23 \mu \mathrm{m}$ ). MP3 and MP4 show the fine grained suspended load and dust storm deposits, respectively. The higher mean grain size in sub-unit B2 confirms higher wind velocity during this period. Sub-unit $\mathrm{C} 1$ resembles fine grained lacustrine sediments with two modal peaks. MP1, MP2 and MP3 in Sub-unit C2 indicate storm, lacustrine and fluvial deposits 


\section{Facies Description}

Shallow lake environment with relatively medium productivity: Light grey(10YR7/1) to light greenish grey $(10 Y 7 / 1)$ laminated carbonaceous clayey silt to sandy silt with high content of root, wood, coal, insects charophyte and also gastropod and ostracod shells. A greenish gray (10Y6/1) bed with very high coal fragments is in depth 35$55 \mathrm{~cm}$.

Arid environment (Aeolian deposition in dry lake bed): Two light brownish green $(10 Y 6 / 2)$ silty sand beds (interbedded with a C1 layer) with very high reworked plant remains and shell fragments. Very Low TOM content.

Shallow lake environment with Low productivity: Light brownish green (10Y6/2) to light green (5Y7/2) laminated clayey silt to sandy silt and silty sand (coarsening upward) with low plant remains, gastropod and ostracod shells. Low TOM and relatively high calcium carbonate content.

Transition between Arid environment and shallow lake: Pale yellow (2.5Y $7 / 3)$ massive sandy silt with plant remains and shell fragments. Low TOM and relatively high calcium carbonate content.

Arid environment (dried up lake bed with seasonal flooding ): Very pale brown $(10 Y R 7 / 3)$ mixed laminations of silt and Aeolian sand rarely containing fine gravel. No shell fragments and plant remains. High muscovite and biotite content in lowermost part. Very low TOM content and medium calcium carbonate content.

Swamp and marsh environment with low productivity: Very pale brown (10YR8/2) massive carbonaceous Clayey silt to sandy silt with gastropod and ostracod shells. Relatively low TOM (decreasing upward) and calcium carbonate content.

Swamp and marsh environment with high productivity: Greenish grey (10Y6/1) to grey $(5 Y 6 / 1)$ massive carbonaceous clayey silt with plant remains and charophytes and also gastropod and ostracod shells. Relatively, high TOM (decreasing upward) and calcium carbonate content.

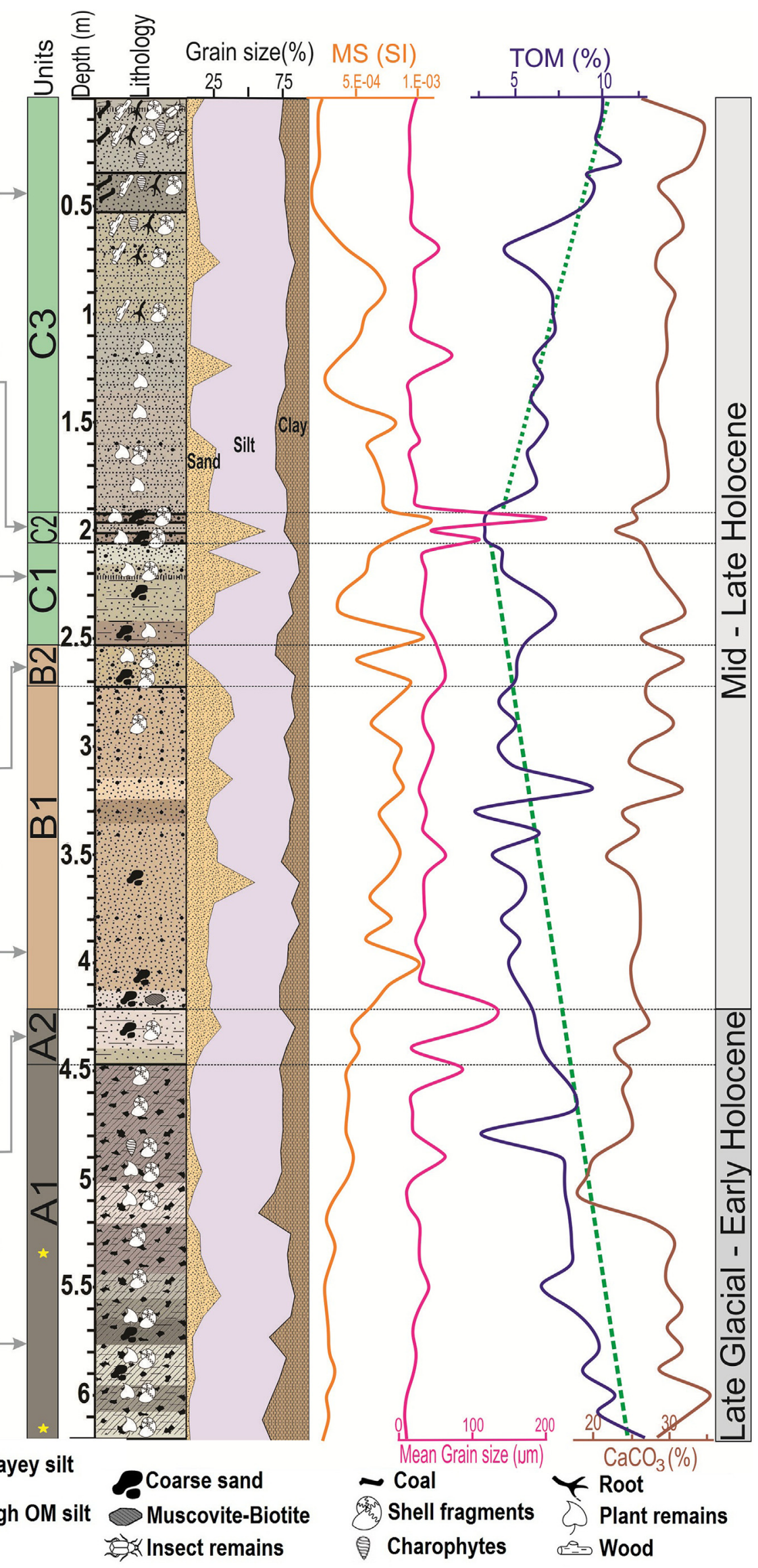

Fig. 3. Lithology and brief facies description of core HMN3. Stars show dating samples. 


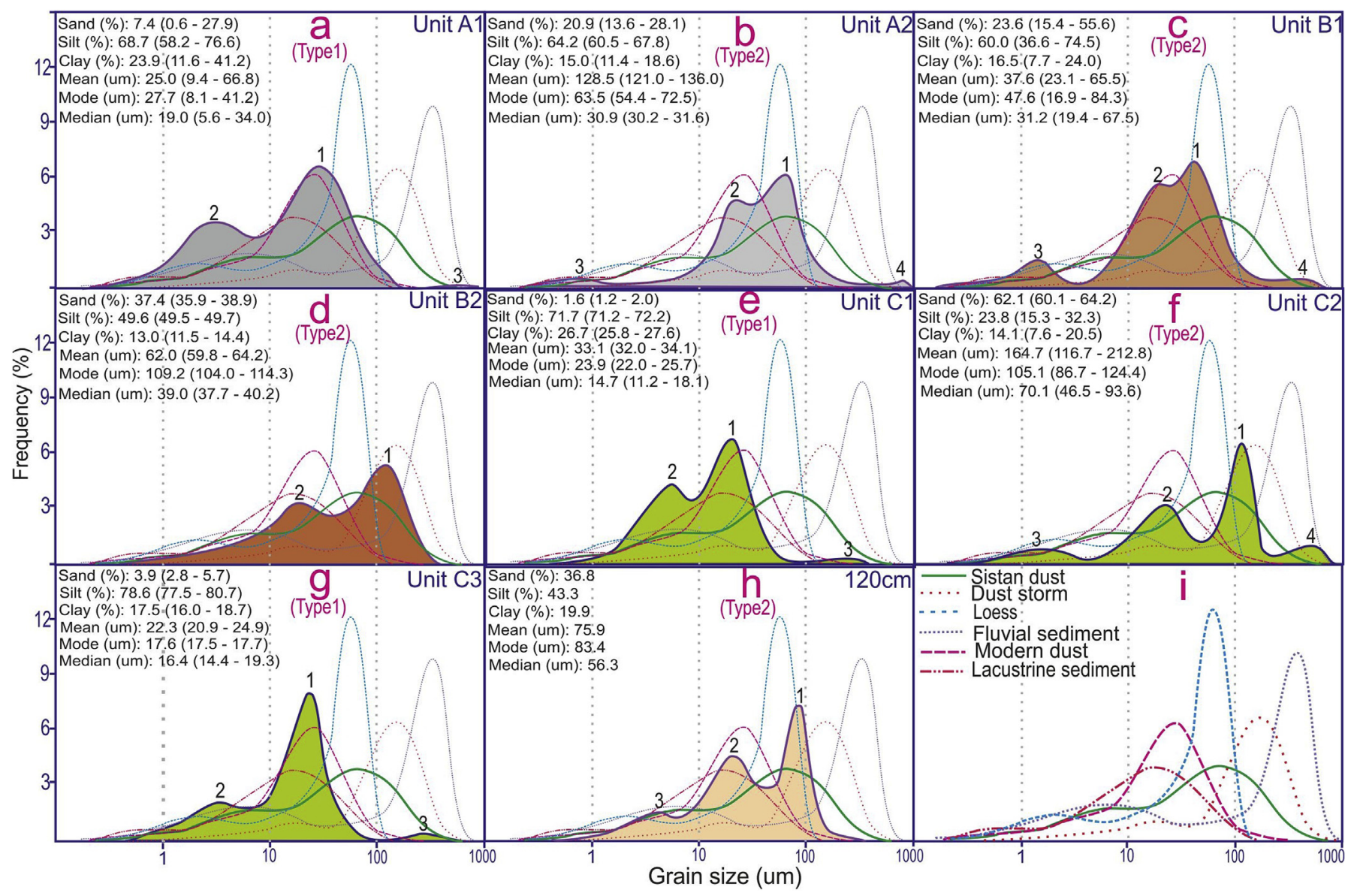

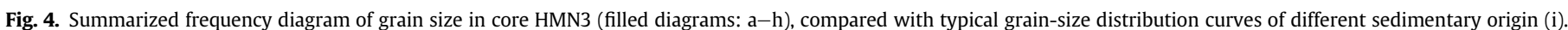

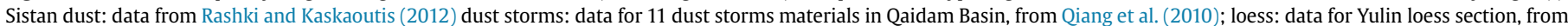

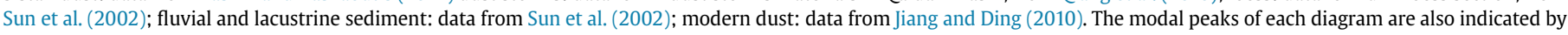
numbers.

respectively. In arid regions, rivers with low discharge are normally not able to carry coarse particles (e.g. $>60 \mu \mathrm{m}$ ) into the centre of a lake basin (De Deckker et al., 1991). McMahon (1906) recorded a storm in 1905 with an average velocity of $39.3 \mathrm{~m} \mathrm{~s}^{-1}$ for a $16 \mathrm{~h}$ period in the Sistan Basin. During that storm, a maximum velocity of $53.6 \mathrm{~m} \mathrm{~s}^{-1}$ was recorded. Comparison of the wind velocity of severe storms in Sistan Basin with the data of Tsoar and Pye (1987) indicates that medium to coarse sand of sub-unit C2 can be easily moved by saltation in severe storms.

In the sub-unit $\mathrm{C} 3$, lacustrine sediments with two MPs of $18-28 \mu \mathrm{m}$ and $2-4 \mu \mathrm{m}$ indicate two fluvio-lacustrine sedimentation phases in different times. Moreover, three aeolian sedimentation periods were observed at depths of 70 (MP1: $81 \mu \mathrm{m}), 120$ (MP1: $83 \mu \mathrm{m})$ and $165 \mathrm{~cm}(\mathrm{MP} 1: 136 \mu \mathrm{m})$ that are relevant to dusty phases.

The correlation between mean grain size and skewness could be applied to infer changes in energy and source of sediments in lake basins (Miousse et al., 2003; Yang and Ding, 2004; Jiang and Ding, 2010). For the sediments $>5 \Phi$ in Fig. 5, skewness shows an inverse correlation with $\Phi$, indicating that coarser grains are correlated with higher skewness. Therefore, samples with grain size more than $5 \Phi$ (less than about $30 \mu \mathrm{m}$ in diameter) are indicative of a low-energy environment (Miousse et al., 2003) or a lacustrine environment in the study area. Grains with less than $5 \Phi$ (more than about $30 \mu \mathrm{m}$ in diameter) are rapidly deposited in a high-energy environment relating to an aeolian source. Based on Figs. 3-5, the sediments in units of A and C (except sub-unit C2) mostly consist of a mixture of lacustrine sediments with minor aeolian sediments. In horizons of 70, 120, 160 and $210-220 \mathrm{~cm}$, the aeolian grains increase dramatically. Sediments of unit B consist of aeolian and fluvial deposits.

\subsection{Grain morphoscopy}

Each depositional environment leaves its morphoscopic fingerprints on clastic grains. Grains of subaqueous environments are generally more rounded and polished with $\mathrm{V}$-shapes in some cases, whereas grains from an aeolian environment are well-rounded and have saucer-shaped depressions, but in some special cases they also show sub-rounded shapes (Sun et al., 2002).

Samples from HMN3 core of different units show all the above features (Fig. 6), suggesting both aeolian and fluvial origins. The observed aeolian features suggest strong wind energy. For instance, Fig. 6d, e, g show regular concavities on round grain surfaces with rounded edges formed by repeated collision of grains. Coarser grains $(100-500 \mu \mathrm{m})$ show evident aeolian features, while finer grains $(<100 \mu \mathrm{m})$ are rarely influenced by wind action. Particles $200-400 \mu \mathrm{m}$ in size are well sorted, which corroborates the saltation mechanism for their transportation, while particles $10-15 \mu \mathrm{m}$ in size are poorly sorted. The poorly sorted grains are representative of a suspension component. 


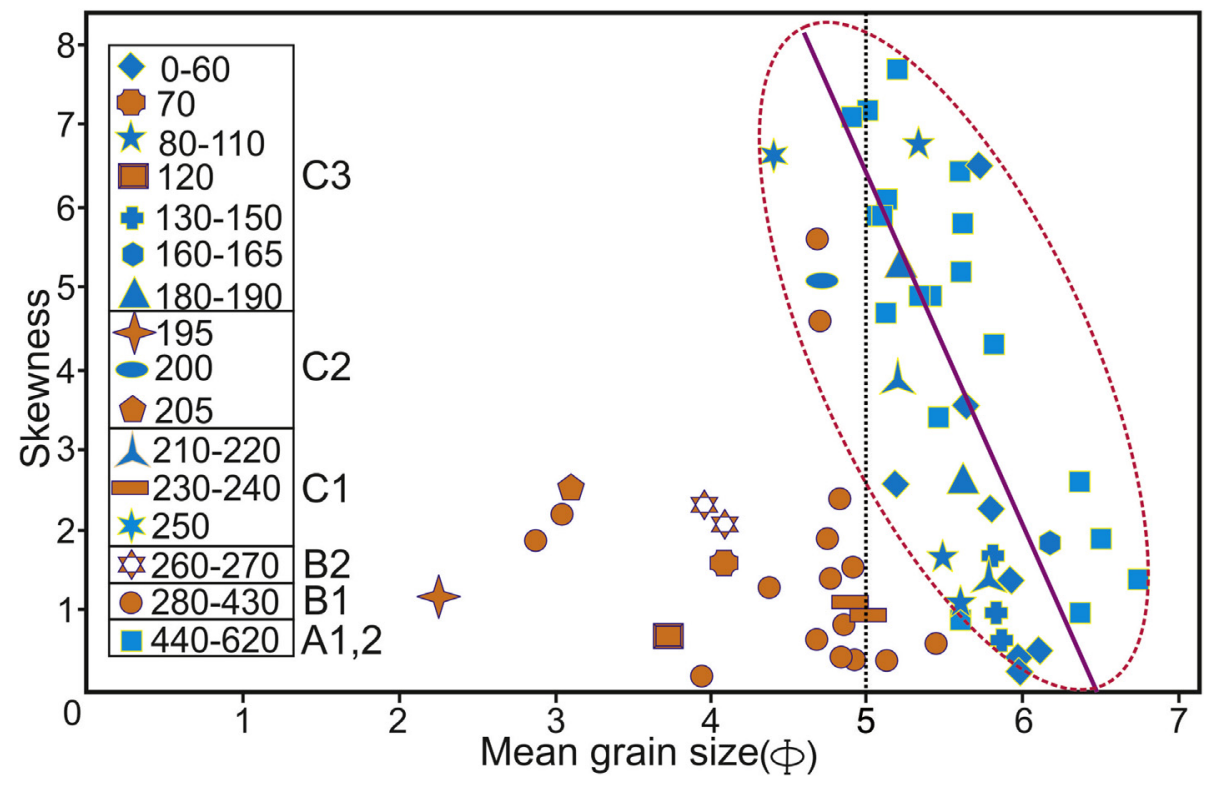

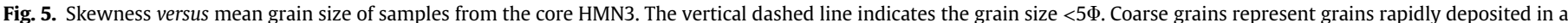

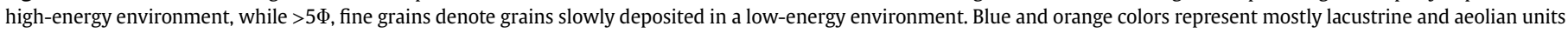

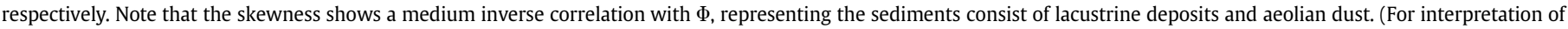
the references to colour in this figure legend, the reader is referred to the web version of this article.).

\subsection{Petrography}

Mud aggregates are the most distinctive feature observed in the studied thin section (Fig. 7), showing temporary desiccation of Lake Hamoun. Various mechanisms have been proposed for the formation of mud aggregates in arid environments: 1) disruption of clay-rich sediments by salt efflorescence due to fluctuating water table and high evaporation rate (Price, 1963; Bowler, 1973); 2) weathering of argillaceous rocks (Nanson et al., 1988); 3) pedogenesis (Rust and Nanson, 1989); and 4) alternative inundation and desiccation of clay rich soils (Freytet and Plalziat, 1982). Clay aggregates may also form through biogenesis forming fecal pellets.

Mud aggregates could be used for palaeoenvironmental studies as they could indicate the alternation of inundation and desiccation periods. Mud aggregates are frequently found in sediments of unit $\mathrm{B}$ and to a lesser extent, unit C. Because mud aggregates do not survive in long-distant aeolian transport (Bowler, 1973), they are indicative of local variations in water table. According to Rashki et al. (2013), high shear velocity winds in the Sistan Basin tend to erode the lake bed and consequently produce dust with relatively
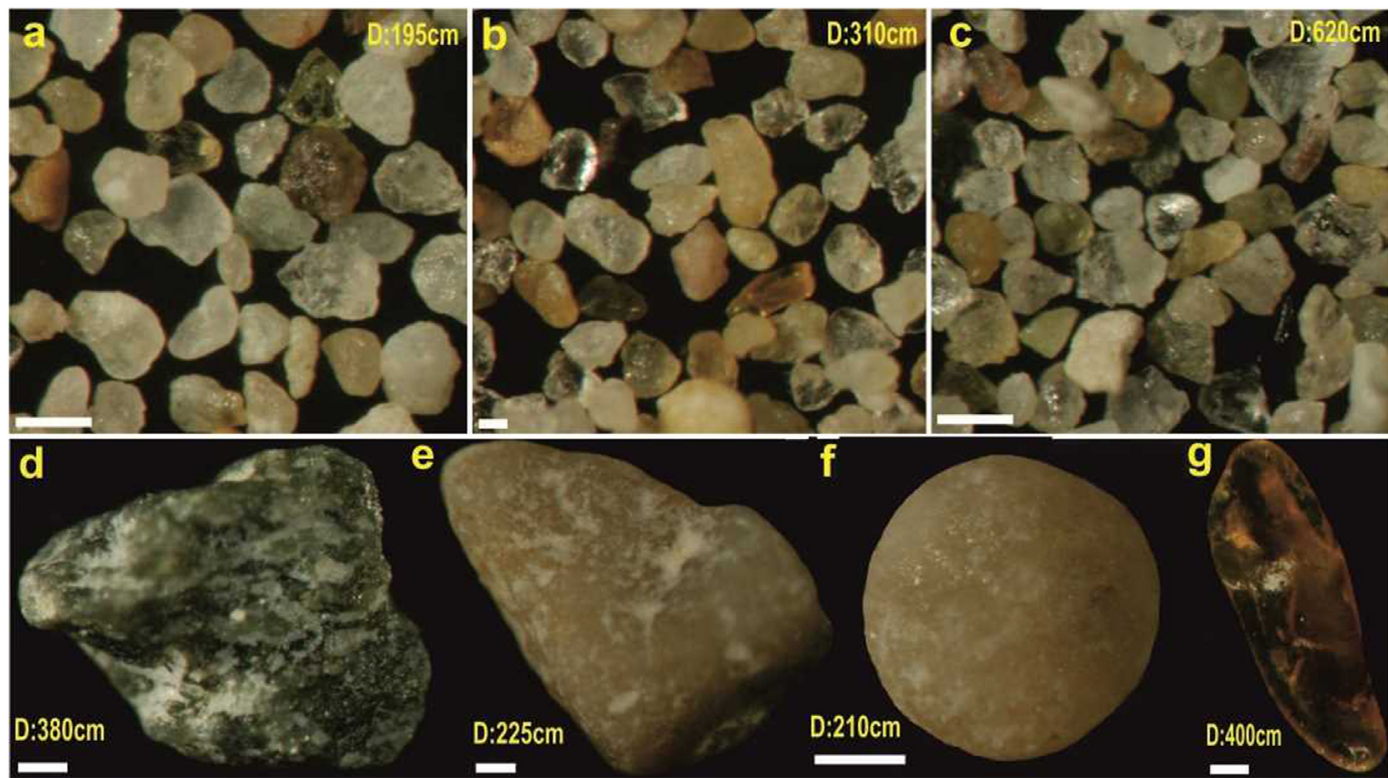

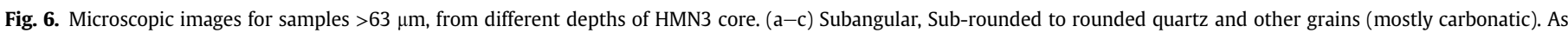

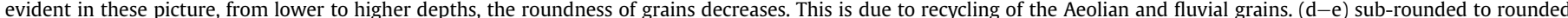

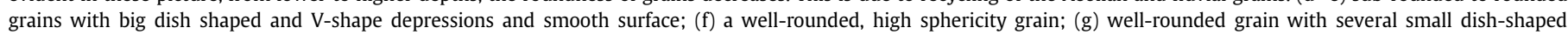
depressions. All images of above samples show obvious Aeolian and fluvial features (Scale bar: $100 \mu \mathrm{m}$ ). 


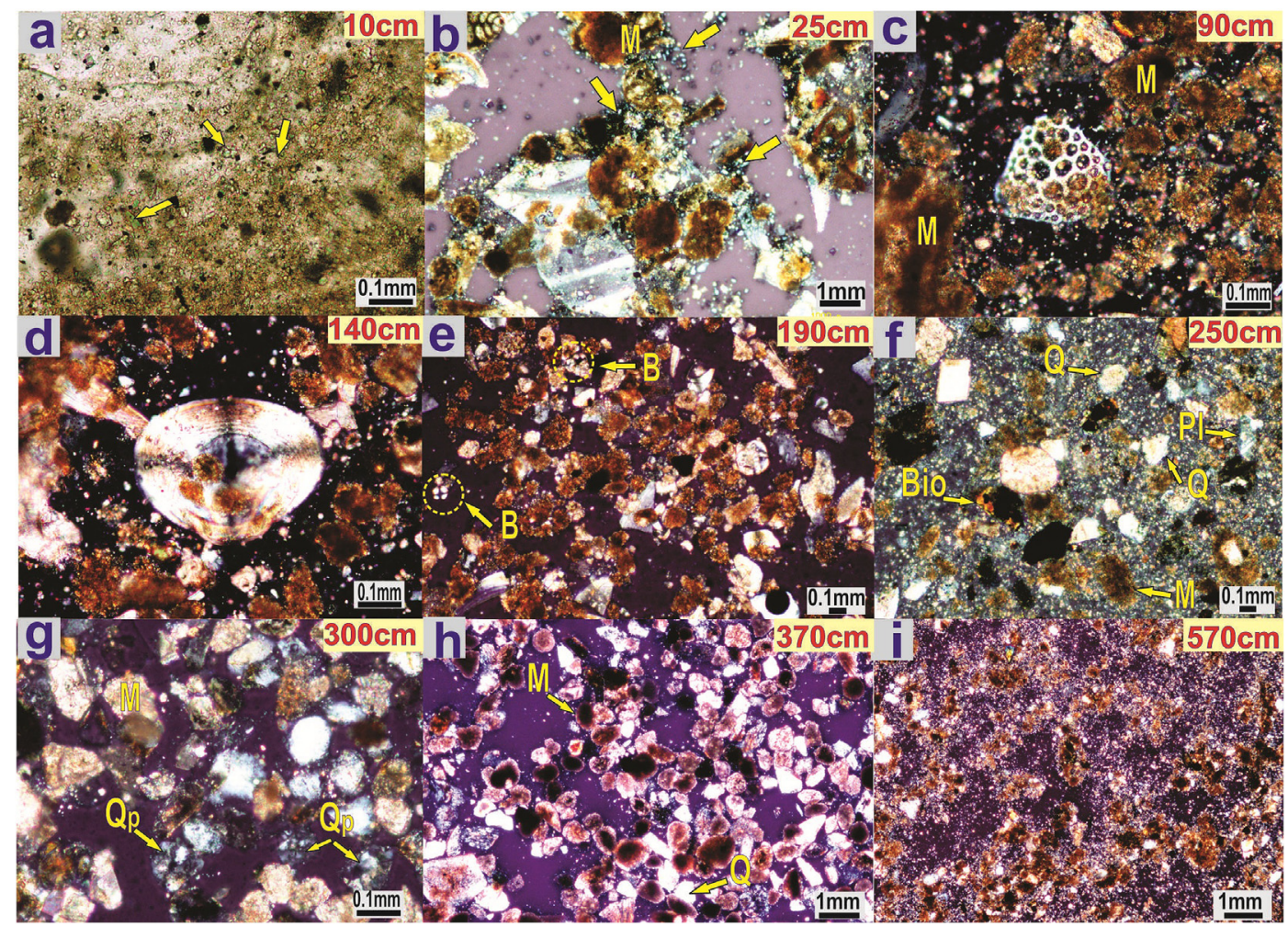

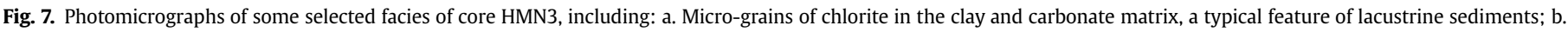

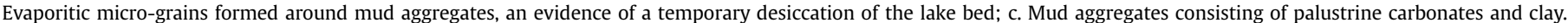

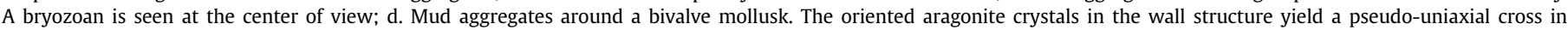

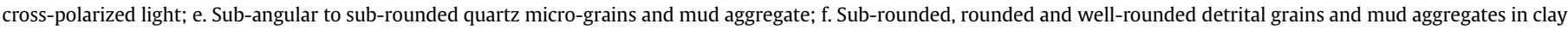

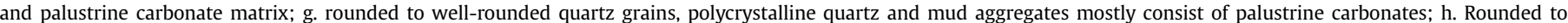

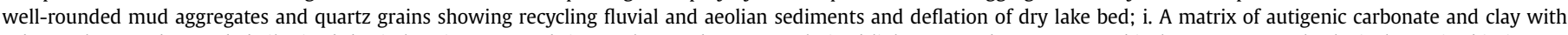

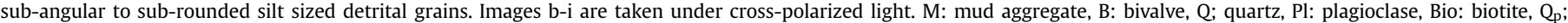
polycrystalline quartz.

high $\mathrm{Na}_{2} \mathrm{O}$ and $\mathrm{MgO}$ content. On the other hand, less strong winds produce dust with higher $\mathrm{Al}_{2} \mathrm{O}_{3}$ and $\mathrm{SiO}_{2}$ from eroding discrete alluvial fans. Therefore, mud aggregate content in aeolian sands is positively correlated with severity of dust storms.

The most frequent detrital mineral in the studied cores is quartz. Polycrystalline quartz with sutured crystal boundaries is also frequent, showing the metamorphic origin of quartz (Adams et al., 1984). Plagioclase, biotite and mafic minerals are mostly altered to chlorite, sericite, carbonates, and clay minerals. The matrix mostly consists of pedogenic carbonates, clay minerals, and minor amounts of evaporites. Chlorite is a relatively abundant mineral in A1 and C3 units, representative of more humid conditions. Rashki et al. (2012) also reported similar minerals in the aeolian dust of the Sistan Basin. Some pieces of gastropods, ostracods, bivalves, bryozoans, sponges, charophytes, and foraminifers were observed in the samples. The foraminifera belong to a saline environment. It seems that they were reworked from older deposits of Neogene sediments (Jux and Kempf, 1983).

\subsection{Palynology}

Several samples were processed for palynological study. However, the samples were barren of pollen. It seems that the long seasonal exposure of lake bed during depositional period is the major destructive factor for pollen preservation. Core samples from more waterlogged areas of Lake Hamoun may be more promising for future palynological investigations.

\section{Discussion}

\subsection{Sediment transport cycle}

Different classes of sediment roundness (sub-angular, subrounded, rounded and well-rounded) with low and high sphericity represent different degrees of reworking. Prevailing winds (N-NW winds) deflate the alluvial fans of northern rivers (Farah Rud, Khash Rud, and Khuspas Rud) and the sedimentary products experience only one cycle of transportation by rivers and wind. The source of these fluvial sediments is the highlands of NE Afghanistan (Rashki et al., 2013). Therefore, these particles are angular to subangular depending on their size, composition and transportation distance. This may happen for sediments carried by the Hirmand and Arghandab Rivers from the Hindu Kush. However, some particles may experience more than one transportation cycle. For example, the Hirmand River can bring sediment into the lake basin and deposit them in the delta (alluvial fans and lakes). These sediments are then transported by winds into areas close to the Hirmand River channel (e.g. Jahannam and Margo desert and Rigestan) and then transported to the lake by water (Fig. 8). This cycle is mentioned by other authors (Smith, 1974; Whitney, 2007; Rashki et al., 2013).

As illustrated in Fig. 8, two major sources of dust could be recognized in the Sistan Basin. The first source (S1) is the Margo desert which is not currently the main source of dust. Some authors believe that this area was severely deflated during Last Glacial Maximum (Jux and Kempf, 1983) and now is covered by gravel pans 


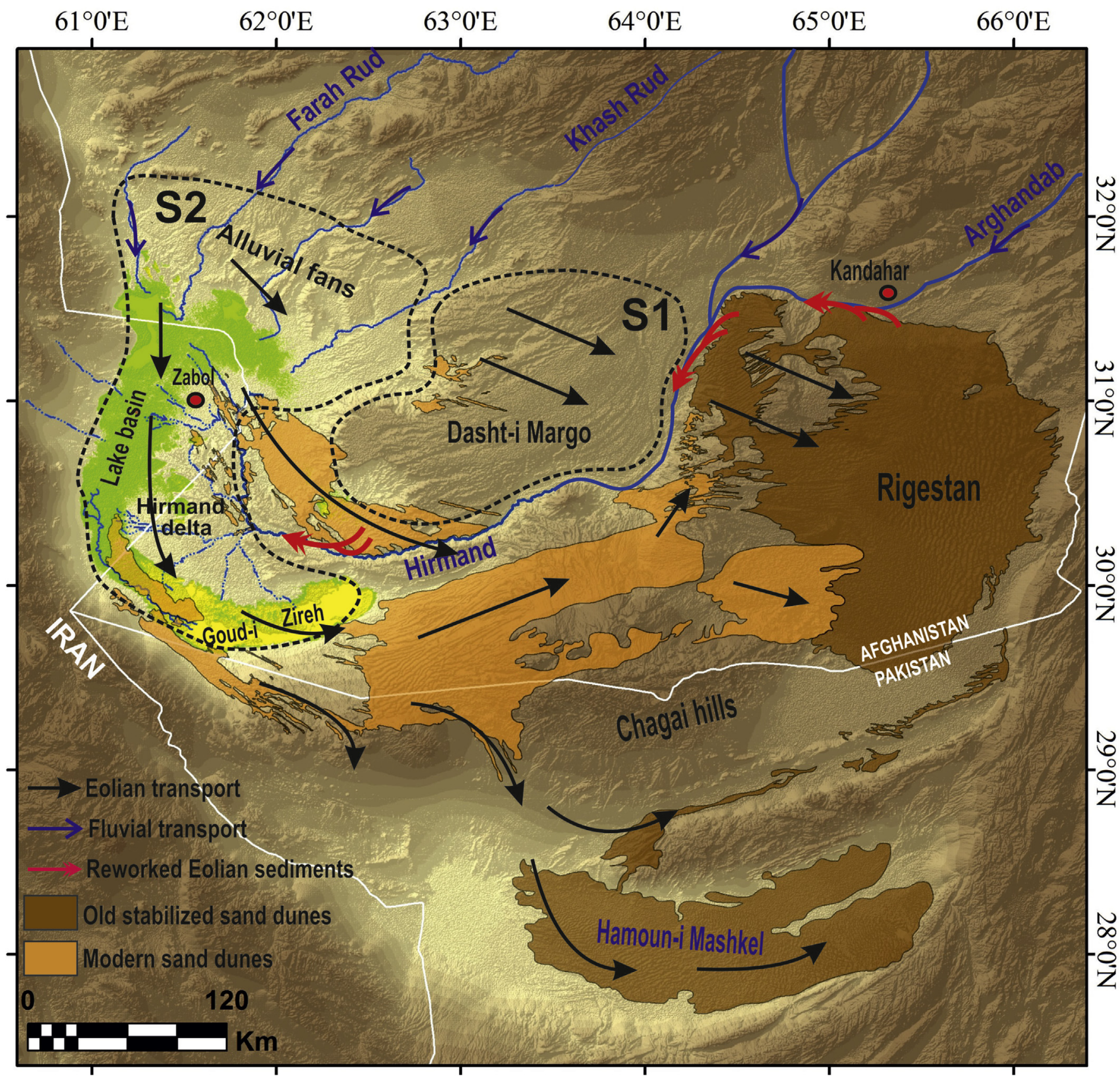

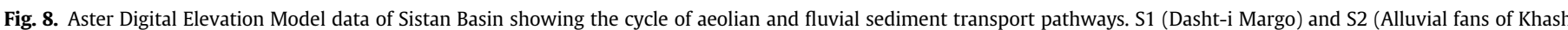
Rud and Farah Rud, Hamoun Lake basin and Goud-i Zireh) are two deflated areas acting as local sources of dust.

preventing wind erosion. The deflated sediments have been deposited in Rigestan where the aeolian sediments are presently stabilized. The darker color of these deposits in satellite images of central and eastern parts of Rigestan differentiates them from younger aeolian sediments (Whitney, 2007).

The second source of dust (S2 in Fig. 8) is located in alluvial fans of northern rivers, lake basin, Hirmand Delta, and Goud-i Zireh. This source supplies the material for the wind-blown deposits transported by prevailing winds, mostly during dry periods (Rashki et al., 2013).

\subsection{Palaeohydrological evolution of Lake Hamoun}

\subsubsection{Unit A (late-glacial to early Holocene)}

During the relatively long period corresponding to unit $A$, the Sistan Basin and/or Hindu Kush Mountains experienced the wettest climate since the late-glacial. According to radiocarbon age data and the stratigraphic position, we attributed this unit to the late-glacial to early Holocene. As shown in Figs. 3 and 4, sand deposition in the basin was low at this time. Low values of MS for sub-units A1 and A2 confirms that the basin received fewer detrital grains in this period. Moreover, wind action was weaker and a more biologically productive environment prevailed. Correlation coefficient between silt (as indicator of lacustrine sedimentation) and calcium carbonate contents $\left(\mathrm{r}^{2}=0.34\right)$ confirms the presence of a permanent lake with limited lake level fluctuations during this period, that consequently prevented palustrine carbonate accumulation. As a barrier, well-developed macrophytic vegetation belts around the lake probably have reduced the detrital input. High TOM content and frequent shallow water gastropod shells (Bithynia sistanica, Lymnaea gedrosiana, Gyraulus euphraticus and G. 
convexiusculus) (Hamzeh, in press), reveals that Lake Hamoun had more stable water levels in early Holocene. More water input provided a favorable condition for a highly productive environment with low or no aeolian deposition. The MP1 event (increasing coarser particles) might be related to snowmelt in the highlands (Owen, 2009) and/or flooding of the rivers due to torrential monsoonal rains. MP2 (finer grains) represents gradual snowmelt during the rest of the year.

At the end of unit A deposition, windblown dust was added to the lacustrine sediments (Fig. 3) by high velocity winds comparable with those of today, which suggests the establishment of a pressure gradient between the mountains and the Sistan Basin due to temperature decrease over the highlands. An aridification trend in the Sistan Basin at this time was probably caused by southward migration of the ITCZ. This time was coeval with abrupt reduction of TOM and carbonate content and disappearing shells. On the other hand, sand fraction increased and coarse sand appears in upper parts of the unit, which is related to high speed winds.

\subsubsection{Unit B (mid Holocene)}

An evident dry condition prevailed on the Sistan Basin and its catchment basin at this time. According to available chronological data, we can only give a rough mid Holocene age to this unit. High sand content and high MS are evidence of high frequency wind storms. The pale yellow, very pale brown and pale brown colours show oxidation of exposed sediments in an arid environment. Very low TOM content, absence of shells and plant remains also indicate dry conditions. Alternating lamination of alluvial silt and aeolian sand grains in this unit confirms the seasonal interplay of shortterm inundation and wind-blown dust deposition under an arid environment. Moreover, the sediment partitioning graphs (Fig. 4) show that medium velocity winds together with seasonal fluvial events were dominant in Lake Hamoun (Rashki and Kaskaoutis, 2012). At the end of this period, the wind velocity increased as a consequence of increasing pressure gradient in the area. The predominance of dust storms at this time is evident (Fig. 4d).

During deposition of sub-unit B2, a relatively wetter period started, most probably suggesting dominance of Mediterranean winter precipitation over the Hindu Kush. The sediment color changed from pale yellow to light brownish grey when Unit B1 transitioned to Unit B2. An abrupt decrease in MS values could be related to changing the situation to a relatively wetter condition. A trace of burrowing at the base and reappearance of gastropod and ostracod shells at the top of the unit also corroborate the wetter conditions.

\subsubsection{Unit C (late Holocene)}

Generally, unit $C$ suggests a periodically dried-up shallow lake similar to present day situation. The base of the unit represents the complete reappearance of the lake due to inflowing water from Rud-i Biaban (Tosi, 1983). Low TOM content, low frequency of shell fragments and rare plant remains in sub-unit C1 show poor productivity of the environment. However, in the upper parts of sub-unit $\mathrm{C} 1$, the productivity increased gradually. Two fluviolacustrine phases (coarser grains) occurred during generally stable conditions, corroborated by deposition of fine silts. Palaeogeographical and palaeohydrologial investigations as well as archaeological studies (Tosi, 1983) show that the rivers were permanently reactivated. Water availability led to establishment of the Shahr-i Sukhteh civilization, the oldest buildings investigated in Hirmand Delta dating to $\sim 6$ ka BP (Tosi, 1983).

Two aeolian sand layers $\sim 5 \mathrm{~cm}$ thick at about 205 and $195 \mathrm{~cm}$ depth suggest two drought events. The lower sand layer contains frequent shell fragments and plant remains, indicating a high productivity condition. After a period of inundation, another drought with severe storms occurred in the area. The lack of shell fragments in the upper sand layer indicates a barren environment north of Hamoun before the time corresponding to this sand layer. Correlation of the drought events and palaeostorms with archaeological findings such as those in Shahr-i Sukhteh civilization could be the subject of research that could be conducted based on more chronological information.

Very low clay fraction in sub-unit C2 could be related to severe winds that removed the finer grains and concentrated coarser ones. Jux and Kempf (1983) believe that during a drought in mid to late Holocene, possibly corresponding to sub-unit C2, the lake considerably shrank in size and consequently the deltaic fan of Hirmand was exposed. The margins of the delta were gradually covered by swamp vegetation. Settlements finally had to be abandoned because of water shortage. This possibility had already been considered by Huntington (Pumpelly, 1905).

After the dry period corresponding to sub-unit of $\mathrm{C} 2$, the climate gradually became wetter. The sediment color changed from brown to brownish grey and greenish grey, TOM content increased and shell fragments appeared suddenly. The lower parts of the sub-unit C3 show that the lake was not permanent in the initial stages. The correlation coefficient between silt and calcium carbonate content in this unit is 0.71 , revealing dominance of a shallow lake with high lake level fluctuations. This condition provided a suitable environment for lacustrine/palustrine freshwater carbonate concentration. As illustrated in Fig. 4, bimodality of fluvio-lacustrine sediments suggests that rivers were flooding in late spring, while during the rest of the year conditions were similar to the modern situation.

A perennial lake prevailed due to increasing water discharge from the high mountains, and vast lands of the Hirmand deltaic fan were cultivated due to water availability. As a result, an economic base was funded in the region for the Pre-Islamic Persian empires of Achaemenid (Dahane-i Gholaman archeological site, Tappe-i Sorkh Dagh near Nad-i Ali) and Sassanid (Kuh-i Khawjeh and Ram Shahrestan) to early Islamic settlements (Zahedan-i Kohneh and south and north of Chakhansur) (Jux and Kempf, 1983; Sajjadi, 2007) (Fig. 2a). Many infrastructures such as dykes, canal systems and domiciles were constructed at this time (Tate, 1910). Environmental conditions during this period were more favorable than during sub-unit C1. Historical evidence shows that the Sistan Basin was known as the breadbasket of western Asia, as agriculture bloomed at this time (Goldsmid, 1875). In contrast, during the Shahr-i Sukhteh civilization, trading and industrial activities such as the processing of Lazuli were the major economic activities (Tosi, 1983). Three dry phases occurred during the interval corresponding to sub-unit C3 (depths 70,120 and $160 \mathrm{~cm}$ ). Comparison with grain size analyses of Rashki and Kaskaoutis (2012) indicates that the wind shear velocity was similar to the modern situation in the first two phases. The Sistan Basin experienced much stronger winds during the last aeolian phase (Figs. 3 and 4).

A charcoal bearing layer is evident at the depth of $35-50 \mathrm{~cm}$, which could be attributed to a large scale wildfire event at the end of the 14th century during an invasion by Turkomen (Author, 1935). However, continuous wind erosion along with lacustrine sedimentation could rework any records of short-term events in the Sistan Basin.

\subsection{Palaeoclimatic implications}

Since the late-glacial, the hydro-climatic regime of interior west Asia has been under the influence of various atmospheric circulation patterns and intensities. High pressure cells of the Siberian Anti-cyclone from the north, low pressure cells belonging to the ISM from the south, and MLW governed the regional climate during 
this period (Ricketts et al., 2001; Dortch et al., 2013) (Fig. 1). The dominance of each of the major climatic systems through time has strongly affected the fragile ecosystems of the eastern Iranian Plateau. In addition, the Holocene hydro-climatic changes have been influenced by the interplay of local (intra-basin) and regional (Hindu Kush mountain) climate receiving moisture from ISM and MLW. In order to increase the precision of our limited chronological data, and to evaluate Holocene palaeoclimatic evolution of the Sistan Basin and climatic forcing factors, we correlated our magnetic susceptibility record with proxy data of ISM, Siberian High and MLW domains to find matching climatic events (Fig. 5). Based on the proxy data and correlations, we divided Holocene palaeoclimate into three phases.

\subsubsection{Phase 1: an ISM-dominated climate?}

The dry and wet periods in Sistan have been determined by the amount of water derived from the Hindu Kush. Higher mean grain size of MP1 in sub-unit A1 (up to $41.2 \mu \mathrm{m}$ ) relative to sub-unit C3 (up to $17.7 \mu \mathrm{m}$ ) corroborates higher river discharge during the early Holocene. High early Holocene ISM-related snowfall and positive glacier mass balances in western Himalaya and Hindu Kush Mountain during the late Quaternary have been documented (Owen et al., 2002b; Dortch et al., 2013; Owen and Dortch, 2014). Owen and Dortch (2014) suggest that Quaternary warm periods increased MLW- and ISM precipitations and consequently led to high glacial mass balance in the semi-arid western Himalayas. On the other hand, cold stages corresponding to ISM retreats resulted in ice preservation on the mountains in spite of decreased MLWassociated precipitation. As a result of high ISM precipitation, ISM-associated glaciers of western Himalayas were responsible for higher water discharge into the Sistan Basin during late-glacial and early Holocene.

The oxygen and carbon isotope studies of Lake Issyk-Kul in Kyrgyzstan show that the lake received more freshwater input (via Tyup and Djergalan Rivers), during the early Holocene due to NW Himalayan ISM-associated glacier melting (Ricketts et al., 2001) (Fig. 9c). Leroy et al. (2013) have also suggested that early Holocene high Caspian Sea level (Fig. 9c) was mainly governed by ISM precipitations over the NW Himalayas (Pamir and Tien-Shan glaciers) brought by Amu-Daria and the Uzboy River (Fig. 1). Adjacent headwaters of major rivers in southwest Asia, such as Indus River and the Ganga-Brahmaputra river system fed by ISM precipitation over NW Himalayas, were flowing with highest discharge during this time (Singh, 1971; Goodbred and Kuehl, 2000). Hence, it could be concluded that the NW Himalayas ISM-associated glaciers as a result of high ISM precipitation were responsible for high runoff to the Sistan Basin during late-glacial and early Holocene.

According to the dated horizon of unit A in our study, the climate of the Sistan Basin during the early Holocene was mostly affected by ISM. This is corroborated by findings from Hotti cave, Oman (Fleitmann et al., 2003), Arabian Sea (Gupta et al., 2003) (Fig. 9e) and monsoon associated glaciers of semi-arid western HimalayanTibetan stages (SWHTS) defined by Dortch et al. (2013) (Fig. 9b).

Proxy records of the Eastern Mediterranean (Bar-Matthews et al., 2003) (Fig. 1), Turkey (Lake Van (Wick et al., 2003)) and western Iran such as Lake Zeribar, Mirabad and Neor (Stevens et al., 2001, 2006; Sharifi et al., 2015) reveal a delayed increase in moisture during the beginning of the Holocene. The moisture increase at early to mid Holocene is correlated with the latter parts of unit A1 in Lake Hamoun (Fig. 9a, d). Hence, during the early Holocene, in addition to ISM-associated precipitation in the Sistan Basin and Hindu Kush, the MLW-associated precipitation elevated the moisture input into the region, especially since the latter parts of the early Holocene. MLW may have possibly contributed to the amount of precipitation in the northern parts of the ISM domain during the early Holocene (Leipe et al., 2013). In contrast to the continental Middle East, various studies have shown that the post-glacial intensification of the ISM on the northern coasts of Indian Ocean caused a dramatic increase in surface water availability at about 13-11.5 ka BP (Van Campo, 1986; Kumaran et al., 2005; Ansari and Vink, 2007), suggesting that ISM was the only climatic forcing factor for Sistan at the late-glacial and the beginning of the Holocene.

Briefly, the early Holocene is characterized by ISM (late-glacial to early Holocene) and MLW (latter parts of early Holocene) maximum intensity. Consequently, the area has received moisture from both sources, as the Sistan Basin experienced a more humid condition.

\subsubsection{Phase2: transitional climate}

The southward migration of ITCZ in mid Holocene (Fleitmann et al., 2007), weakening of ISM over the area (especially over Western Hindu Kush) and ongoing MLW (Sharifi et al., 2015) imposed an arid climate on the Sistan Basin. Throughout the earlymid Holocene transition, the decrease in precipitation in northern limit of the ISM (northwestern Himalaya, containing Karakoram and Hindu Kush) was greater than in southern parts such as the western Arabian Sea region (Leipe et al., 2013). The time of shift from ISM-associated precipitation to Mediterranean winter precipitation in northern Oman was around mid-Holocene (Fleitmann et al., 2007). Geological evidence also suggest that during this period, the African humid period shifted toward more arid conditions (Ritchie et al., 1985). Ricketts et al. (2001) indicated more arid conditions since $6.9 \mathrm{ka}$ BP in Lake Issyk-Kul which was attributed to weakening of the ISM. Their finding is supported by research by Rhodes et al. (1996) in other basins in CA. An approximately 4000 year low Caspian Sea level period starting from $7.5 \mathrm{ka}$ BP has been reported by Leroy et al. (2013). The dryness of northern Iran at this time is also shown by the presence of loess deposits along the Caspian Sea coasts and in the foothills of the Alborz Mountains (Frechen et al., 2009). Accordingly, the weakening of the ISM and southward movement of the ITCZ during the mid Holocene caused more spring precipitation over the Zagros Mountains and development of Zagros oak forests (Djamali et al., 2010).

The time period corresponding to unit B coincides with a cold phase MLW associated SWHTS in CA and Himalaya, such as K2, Hunza and Nanga Parbat (Dortch et al., 2013). Altogether, it seems that during the period corresponding to unit B, decreasing ISM and MLW associated precipitation over the mountains of NW Himalayas as a result of a cold phase, were responsible for water shortage and severe wind storms in the area.

\subsubsection{Phase3: modern MLW- dominated climate}

Palaeoclimatic records show since the mid Holocene to the present time, the climate of Sistan and its catchment area more or less oscillated around a steady state. The gradual expansion of Zagros oak woodland during this time is explained as a consequence of weakening the ISM and strengthening the MLW, bringing Mediterranean-type precipitation into the Iranian plateau (Djamali et al., 2010). Recent investigation in a peat mire at Neor Lake in NW Iran (Sharifi et al., 2015), and SE Caspian Sea (Leroy et al., 2013), show unstable climate conditions and frequent lake level fluctuations during the mid to late Holocene. The palaeolimnology of Lake Issyk-Kul also shows that from 4900 yrs BP to the present, the palaeoclimatic data are relatively constant, implying conditions similar to modern conditions, during which moisture is mostly derived from MLW (Ricketts et al., 2001). By comparing the mid to late Holocene palaeoenvironment of Sistan with that of the western Iranian plateau, one can conclude that during the late Holocene, MLW-induced winter precipitation dominated in the area (Fig. 9). 

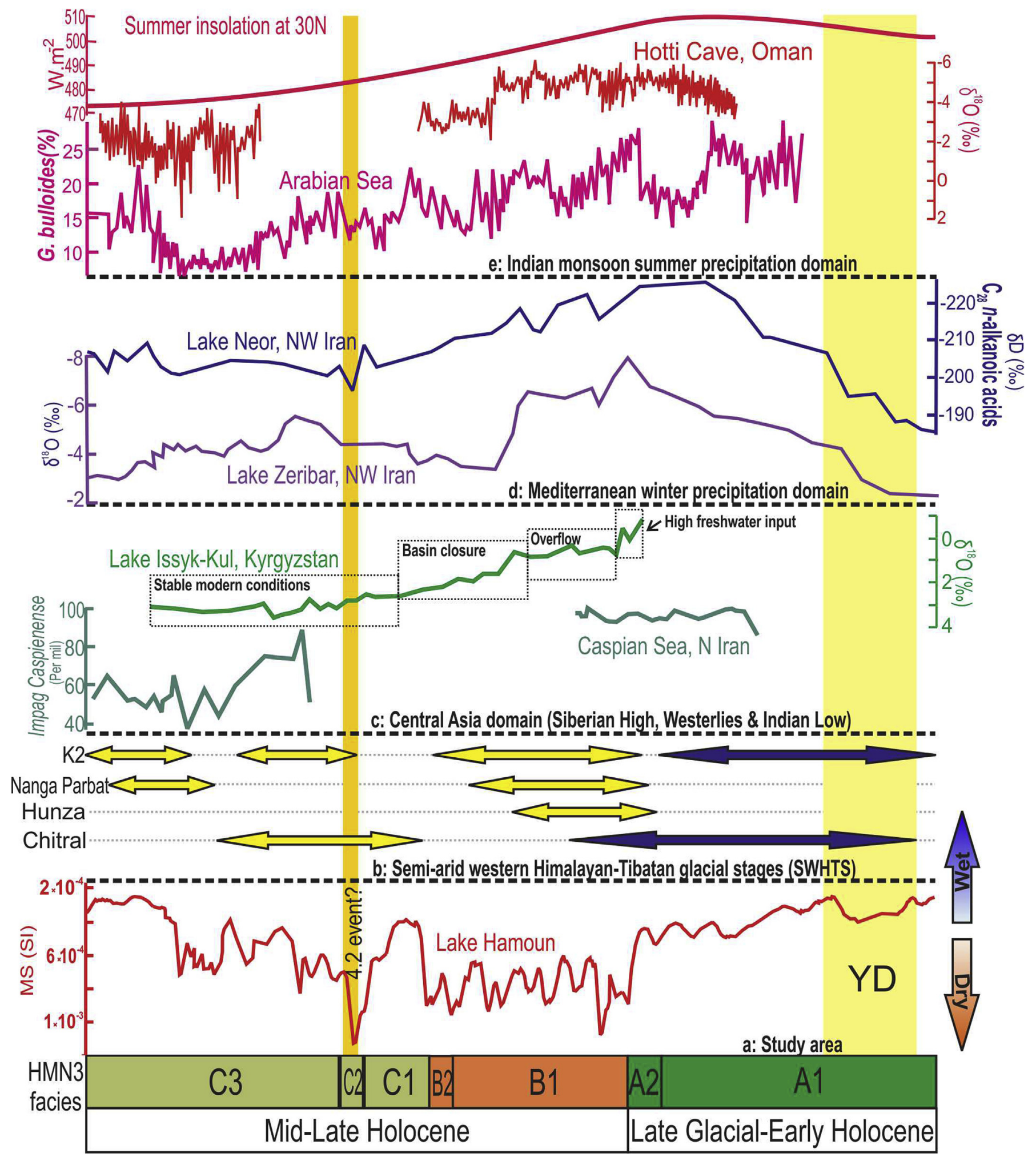

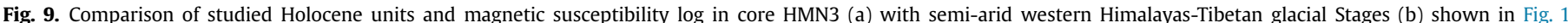

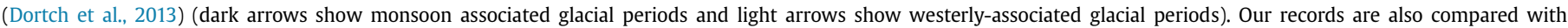

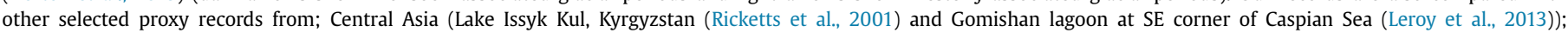

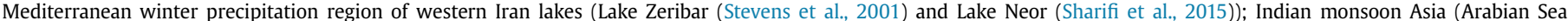
(Gupta et al., 2003), Hotti Cave, Oman (Fleitmann et al., 2003)) and summer insolation at $30^{\circ} \mathrm{N}$ (Berger and Loutre, 1991). 


\section{Conclusions}

The sediment core from Lake Hamoun, SE Iran, represents a late-glacial and Holocene record of dust and fluvio-lacustrine deposition and provides new insights about the palaeohydrological evolution of the Sistan Basin. Grain size distribution, petrographical characteristics, and basin geochemical measurements of core sediments suggest that:

- Late-glacial to early Holocene in Sistan Basin was characterized by a high productive lake with relatively stable water levels. The basin was being fed by both MLW-associated and ISM-associated precipitation over Hindu Kush mountains. The position of ITCZ made the ISM as a major possible source of moisture for SE Iran, Afghanistan and Pakistan.

- During the early to mid Holocene, southward migration of ITCZ led to weakening of the ISM, and consequently drought periods in Sistan Basin and semi-arid conditions over NW Himalaya. Establishment of a high pressure gradient between the Sistan depression and the high Hindu Kush Mountains caused the occurrence of severe and frequent dust storms over the area.

- From mid to late Holocene onwards, the hydroclimatic regime of the Sistan Basin and NW Himalaya have been mostly governed by MLW-associated precipitation. In comparison to late-glacial to early Holocene, lake level dropped and the productivity of Lake Hamoun was reduced. Frequent lake level fluctuations show unstable climate of the Sistan Basin during mid to late Holocene.

As the Sistan Basin has been the host of great civilizations from mid to late Holocene, it is needed to establish higher resolution chronologies for the sediments of studied cores (especially in the sub-unit (1) and future palaeo-records to correlate hydrological evolution of Lake Hamoun with socio-economic changes of human communities. As the lake sediments are barren palynologically, it is recommended to use biogeochemical proxies as an alternative proxy of the past hydroclimatic conditions.

\section{Acknowledgements}

We acknowledge Mr M. Baziar for his help in coring and appreciate $\mathrm{Mr} \mathrm{G}$. Baskaleh for his assistance in laboratory works. This study has been supported by the Iranian National Institute for Oceanography and Atmospheric Sciences in the framework of a project entitled 'Environmental Monitoring and Environmental Forecasting of the Iranian Internal Lakes (No.391-012-01)'.

\section{References}

Adams, A.E., MacKenzie, W.S., Guilford, C., 1984. Atlas of Sedimentary Rocks Under the Microscope. Wiley, Van Nostrand Reinhold (UK), Longman.

Alizadeh-Choobari, O., Zawar-Reza, P., Sturman, A., 2014. The "wind of 120 days" and dust storm activity over the Sistan Basin. Atmospheric Research 143, $328-341$.

An, C.-B., Zhao, J., Tao, S., Lv, Y., Dong, W., Li, H., Jin, M., Wang, Z., 2011. Dust variation recorded by lacustrine sediments from arid Central Asia since $15 \mathrm{cal} \mathrm{ka} \mathrm{BP}$ and its implication for atmospheric circulation. Quaternary Research 75, 566-573.

An, F., Ma, H., Wei, H., Lai, Z., 2012. Distinguishing aeolian signature from lacustrine sediments of the Qaidam Basin in northeastern Qinghai-Tibetan Plateau and its palaeoclimatic implications. Aeolian Research 4, 17-30.

Annandale, N., Prashad, B., 1919. The Mollusca fauna of the inland waters of Baluchistan and of Seistan. Records of the Indian Museum 18, 18-62.

Ansari, M.H., Vink, A., 2007. Vegetation history and palaeoclimate of the past $30 \mathrm{kyr}$ in Pakistan as inferred from the palynology of continental margin sediments off the Indus delta. Review of Palaeobotany and Palynology 145, 201-216.

Arz, H.W., Lamy, F., Pätzold, J., Müller, P.J., Prins, M., 2003. Mediterranean moisture source for an early-Holocene humid period in the northern Red Sea. Science $300,118-121$.

Author, U., 1935. In: Bahar, M.S.A. (Ed.), Tarikh-i Sistan (The History of Sistan). Kalaleh khavar, Tehran, p. 417.
Bar-Matthews, M., Ayalon, A., Gilmour, M., Matthews, A., Hawkesworth, C.J., 2003 Sea-land oxygen isotopic relationships from planktonic foraminifera and speleothems in the Eastern Mediterranean region and their implication for paleorainfall during interglacial intervals. Geochimica et Cosmochimica Acta 67, 3181-3199.

Barlow, M., Cullen, H., Lyon, B., 2002. Drought in central and southwest Asia: La Niña, the warm pool, and Indian Ocean precipitation. Journal of Climate 15, 697-700.

Berger, A., Loutre, M.-F., 1991. Insolation values for the climate of the last 10 million years. Quaternary Science Reviews 10, 297-317.

Boomer, I., Aladin, N., Plotnikov, I., Whatley, R., 2000. The palaeolimnology of the Aral Sea: a review. Quaternary Science Reviews 19, 1259-1278.

Bottema, S., 1986. A late Quaternary pollen diagram from Lake Urmia (northwestern Iran). Review of palaeobotany and palynology 47, 241-261.

Bowler, J., 1973. Clay dunes: their occurrence, formation and environmental significance. Earth Science Reviews 9, 315-338.

Charts, M.S.C., 2000. Revised Washable Edition. Gretag Macbeth. New Windsor, NY.

Chen, F., Yu, Z., Yang, M., Ito, E., Wang, S., Madsen, D.B., Huang, X., Zhao, Y., Sato, T. John B Birks, H., 2008. Holocene moisture evolution in arid central Asia and its out-of-phase relationship with Asian monsoon history. Quaternary Science Reviews 27, 351-364.

De Deckker, P., Corrège, T., Head, J., 1991. Late Pleistocene record of cyclic eolian activity from tropical Australia suggesting the Younger Dryas is not an unusual climatic event. Geology 19, 602-605.

Djamali, M., Akhani, H., Andrieu-Ponel, V., Braconnot, P., Brewer, S., de Beaulieu, J.L., Fleitmann, D., Fleury, J., Gasse, F., Guibal, F., 2010. Indian Summer Monsoon variations could have affected the early-Holocene woodland expansion in the Near East. The Holocene 20, 813-820.

Djamali, M., de Beaulieu, J.-L., Andrieu-Ponel, V., Berberian, M., Miller, N.F. Gandouin, E., Lahijani, H., Shah-Hosseini, M., Ponel, P., Salimian, M., 2009a. A late Holocene pollen record from Lake Almalou in NW Iran: evidence for changing land-use in relation to some historical events during the last 3700 years. Journal of Archaeological Science 36, 1364-1375.

Djamali, M., De Beaulieu, J-L, Miller, N.F. Andrieu-Ponel, V., Ponel, P. Lak, R. Sadeddin, N., Akhani, H., Fazeli, H., 2009b. Vegetation history of the SE section of the Zagros mountains during the last five millennia; a pollen record from the Maharlou lake, Fars province, Iran. Vegetation History and Archaeobotany 18, 123-136.

Djamali, M., Kürschner, H., Akhani, H., de Beaulieu, J.-L., Amini, A., AndrieuPonel, V., Ponel, P., Stevens, L., 2008. Palaeoecological significance of the spores of the liverwort Riella (Riellaceae) in a late Pleistocene long pollen record from the hypersaline Lake Urmia, NW Iran. Review of Palaeobotany and Palynology 152, 66-73.

Dortch, J.M., Owen, L.A., Caffee, M.W., 2013. Timing and climatic drivers for glaciation across semi-arid western Himalayan-Tibetan orogen. Quaternary Science Reviews 78, 188-208.

Dykoski, C.A., Edwards, R.L., Cheng, H., Yuan, D., Cai, Y., Zhang, M., Lin, Y., Qing, J., An, Z., Revenaugh, J., 2005. A high-resolution, absolute-dated Holocene and deglacial Asian monsoon record from Dongge Cave, China. Earth and Planetary Science Letters 233, 71-86

Enzel, Y., Ely, L., Mishra, S., Ramesh, R., Amit, R., Lazar, B., Rajaguru, S., Baker, V. Sandler, A., 1999. High-resolution Holocene environmental changes in the Thar Desert, northwestern India. Science 284, 125-128.

Fleitmann, D., Burns, S.J., Mangini, A., Mudelsee, M., Kramers, J., Villa, I., Neff, U., AlSubbary, A.A., Buettner, A., Hippler, D., 2007. Holocene ITCZ and Indian monsoon dynamics recorded in stalagmites from Oman and Yemen (Socotra). Quaternary Science Reviews 26, 170-188.

Fleitmann, D., Burns, S.J., Mudelsee, M., Neff, U., Kramers, J., Mangini, A., Matter, A. 2003. Holocene forcing of the Indian monsoon recorded in a stalagmite from southern Oman. Science 300, 1737-1739.

Frechen, M., Kehl, M., Rolf, C., Sarvati, R., Skowronek, A., 2009. Loess chronology of the Caspian lowland in northern Iran. Quaternary International 198, 220-233.

Freytet, P., Plalziat, J.C., 1982. Continental Carbonate Sedimentation and Pedogenesis: Late Cretaceous and Early Tertiary of Southern France. E. Schweizerbartsche Verlagsbuchhandlung.

Gasse, F., 2000. Hydrological changes in the African tropics since the last glacial maximum. Quaternary Science Reviews 19, 189-211.

Goldsmid, F., 1875. Captain the Hon. G. Napier's journey on the Turcoman Frontier of Persia. In: Proceedings of the Royal Geographical Society of London. JSTOR, pp. 166-182.

Goodbred, S.L., Kuehl, S.A., 2000. Enormous Ganges-Brahmaputra sediment discharge during strengthened early Holocene monsoon. Geology 28, 1083-1086.

Griffiths, H.I., Schwalb, A., Stevens, L.R., 2001. Evironmental change in southwestern Iran: the Holocene ostracod fauna of Lake Mirabad. The Holocene 11, 757-764.

Gupta, A.K., Anderson, D.M., Overpeck, J.T., 2003. Abrupt changes in the Asian southwest monsoon during the Holocene and their links to the North Atlantic Ocean. Nature 421, 354-357.

Hafezi Moghaddas, N., 2012. The role of soil engineering in producing bank erosion and morphological changes of Sistan River Archives of Applied Science Research 4.

Hamzeh, M.A., 2015. Paleoenvironment and Paleoclimate Reconstruction of SE Iran, by Using Holocene Sedimentology of Hamoon Lake, PhD thesis, Faculty of Geology. Ferdowsi University of Mashhad (in press).

Hedin, S., 1910. Zu Land nach Indien durch Persien. Seistan, Belutschistan. F.A.Brockhaus, Leipzig. 
Heiri, O., Lotter, A.F., Lemcke, G., 2001. Loss on ignition as a method for estimating organic and carbonate content in sediments: reproducibility and comparability of results. Journal of Paleolimnology 25, 101-110.

Jiang, H., Ding, Z., 2010. Eolian grain-size signature of the Sikouzi lacustrine sediments (Chinese Loess Plateau): implications for Neogene evolution of the East Asian winter monsoon. Geological Society of America Bulletin 122, 843-854.

Jux, U., Kempf, K., 1983. Regional geology of Sistan (Southwest Afghanistan). Prehistoric Sistan 1, 5-60.

Kehl, M., 2009. Quaternary climate change in Iran-the state of knowledge. Erdkunde 1-17.

Konert, M., Vandenberghe, J., 1997. Comparison of laser grain size analysis with pipette and sieve analysis: a solution for the underestimation of the clay fraction. Sedimentology 44, 523-535.

Krumsiek, K., 1980. Zur plattentektonischen Entwicklung des indo-iranischen Raumes:(Resultate paläomagnetischer Untersuchungen in Afghanistan). E. Schweizerbart.

Kumaran, K., Nair, K., Shindikar, M., Limaye, R.B., Padmalal, D., 2005. Stratigraphical and palynological appraisal of the Late Quaternary mangrove deposits of the west coast of India. Quaternary Research 64, 418-431.

Lambert, N.F., 2010. A Multiproxy High Resolution Paleoclimate Study of Lake Mirabad, Iran. California State University, Long Beach.

Leipe, C., Demske, D., Tarasov, P.E., 2013. A Holocene pollen record from the northwestern Himalayan lake Tso Moriri: implications for palaeoclimatic and archaeological research. Quaternary International 384, 93-112.

Leroy, S.A., Kakroodi, A.A., Kroonenberg, S., Lahijani, H.K., Alimohammadian, H. Nigarov, A., 2013. Holocene vegetation history and sea level changes in the SE corner of the Caspian Sea: relevance to SW Asia climate. Quaternary Science Reviews 70, 28-47.

McMahon, H., 1906. Recent survey and exploration in Seistan. The Geographical Journal 28, 209-228.

Middleton, G.V., 1976. Hydraulic interpretation of sand size distributions. The Journal of Geology 405-426.

Miousse, L., Bhiry, N., Lavoie, M., 2003. Isolation and water-level fluctuations of Lake Kachishayoot, northern Quebec, Canada. Quaternary Research 60, 149-161.

Nanson, G.C., Young, R., Price, D., Rust, B., 1988. Stratigraphy, sedimentology and late Quaternary chronology of the Channel country of western Queensland. Fluvial Geomorphology of Australia 151-175.

Owen, L.A., 2009. Latest Pleistocene and Holocene glacier fluctuations in the Himalaya and Tibet. Quaternary Science Reviews 28, 2150-2164.

Owen, L.A., Caffee, M.W., Bovard, K.R., Finkel, R.C., Sharma, M.C., 2006. Terrestria cosmogenic nuclide surface exposure dating of the oldest glacial successions in the Himalayan orogen: Ladakh Range, northern India. Geological Society of America Bulletin 118, 383-392.

Owen, L.A., Dortch, J.M., 2014. Nature and timing of Quaternary glaciation in the Himalayan-Tibetan orogen. Quaternary Science Reviews 88, 14-54.

Owen, L.A., Finkel, R.C., Barnard, P.L., Haizhou, M., Asahi, K., Caffee, M.W. Derbyshire, E., 2005. Climatic and topographic controls on the style and timing of late Quaternary glaciation throughout Tibet and the Himalaya defined by ${ }^{10} \mathrm{Be}$ cosmogenic radionuclide surface exposure dating. Quaternary Science Reviews 24, 1391-1411.

Owen, L.A., Finkel, R.C., Caffee, M.W., Gualtieri, L., 2002a. Timing of multiple late Quaternary glaciations in the Hunza Valley, Karakoram Mountains, northern Pakistan: defined by cosmogenic radionuclide dating of moraines. Geological Society of America Bulletin 114, 593-604.

Owen, L.A., Kamp, U., Spencer, J.Q. Haserodt, K., 2002b. Timing and style of Late Quaternary glaciation in the eastern Hindu Kush, Chitral, northern Pakistan: review and revision of the glacial chronology based on new optically stimulated luminescence dating. Quaternary International 97, 41-55.

Price, W.A., 1963. Physicochemical and environmental factors in clay dune genesis. Journal of Sedimentary Research 33.

Pumpelly, R., 1905. Explorations in Turkestan with an Account of the Basin of Eastern Persia and Sistan; Expedition of 1903 under Raphael Pumpelly. Carnegie Institute of Washington, Washington, DC.

Qiang, M., Lang, L., Wang, Z., 2010. Do fine-grained components of loess indicate westerlies: insights from observations of dust storm deposits at Lenghu (Qaidam Basin, China). Journal of Arid Environments 74, 1232-1239.

Rashki, A., Eriksson, P., Rautenbach, C.d.W., Kaskaoutis, D., Grote, W., Dykstra, J. 2013. Assessment of chemical and mineralogical characteristics of airborne dust in the Sistan region, Iran. Chemosphere 90, 227-236.

Rashki, A., Kaskaoutis, D., 2012. Changes of Permanent Lake Surfaces, and Their Consequences for Dust Aerosols and Air Quality. The Hamoun Lakes of the Sistan Area, Iran.

Rashki, A., Kaskaoutis, D.G., Rautenbach, C., Eriksson, P.G., Qiang, M., Gupta, P., 2012 Dust storms and their horizontal dust loading in the Sistan region, Iran. Aeolian Research 5, 51-62.

Reimer, P.J., Bard, E., Bayliss, A., Beck, J.W., Blackwell, P.G., Bronk Ramsey, C., Buck, C.E., Cheng, H., Edwards, R.L., Friedrich, M., 2013. IntCal13 and Marine13 Radiocarbon Age Calibration Curves 0-50,000 Years Cal BP.
Rhodes, T.E., Gasse, F., Lin, R., Fontes, J.-C., Wei, K., Bertrand, P., Gibert, E., Mélières, F., Tucholka, P., Wang, Z. 1996. A late Pleistocene-Holocene lacustrine record from Lake Manas, Zunggar (northern Xinjiang, western China). Palaeogeography, Palaeoclimatology, Palaeoecology 120, 105-121.

Richards, B.W., Owen, L.A., Rhodes, E.J., 2000. Timing of Late Quaternary glaciations in the Himalayas of northern Pakistan. Journal of Quaternary Science 15, $283-297$.

Ricketts, R.D., Johnson, T.C., Brown, E.T., Rasmussen, K.A., Romanovsky, V.V., 2001. The Holocene paleolimnology of Lake Issyk-Kul, Kyrgyzstan: trace element and stable isotope composition of ostracodes. Palaeogeography, Palaeoclimatology, Palaeoecology 176, 207-227.

Ritchie, J., Eyles, C., Haynes, C.V., 1985. Sediment and pollen evidence for an early to mid-Holocene humid period in the eastern Sahara. Nature 314, 352-355.

Rust, B.R., Nanson, G.C., 1989. Bedload transport of mud as pedogenic aggregates in modern and ancient rivers. Sedimentology 36, 291-306.

Sajjadi, S., 2007. Wall painting from Dahaneh-ye Gholaman (Sistan). Ancient Civilizations from Scythia to Siberia 13, 1-2.

Schieber, J., Southard, J., Thaisen, K., 2007. Accretion of mudstone beds from migrating floccule ripples. Science 318, 1760-1763.

Seong, Y.B., Owen, L.A., Bishop, M.P., Bush, A., Clendon, P., Copland, L., Finkel, R., Kamp, U., Shroder, J.F., 2007. Quaternary glacial history of the Central Karakoram. Quaternary Science Reviews 26, 3384-3405.

Seong, Y.B., Owen, L.A., Yi, C., Finkel, R.C., 2009. Quaternary glaciation of Muztag Ata and Kongur Shan: evidence for glacier response to rapid climate changes throughout the Late Glacial and Holocene in westernmost Tibet. Geological Society of America Bulletin 121, 348-365.

Sharifi, A., Pourmand, A., Canuel, E.A., Ferer-Tyler, E., Peterson, L.C., Aichner, B. Feakins, S.J., Daryaee, T., Djamali, M., Naderi Beni, A., 2015. Abrupt climate variability since the last deglaciation based on a high-resolution, multi-proxy peat record from NW Iran: the hand that rocked the cradle of civilization? Quaternary Science Reviews 123, 215-230.

Singh, G., 1971. The Indus valley culture: seen in the context of post-glacial climatic and ecological studies in North-West India. Archaeology \& Physical Anthropology in Oceania 177-189.

Sivall, T.R., 1977. Synoptic-climatological study of the Asian SUMMER monsoon in Afghanistan. Geografiska Annaler Series A, Physical Geography 67-87.

Smith, G.I., 1974. Quaternary deposits in southwestern Afghanistan. Quaternary Research 4, 39-52.

Staubwasser, M., Sirocko, F., Grootes, P., Segl, M., 2003. Climate change at the 4.2 ka BP termination of the Indus valley civilization and Holocene south Asian monsoon variability. Geophysical Research Letters 30, 372-387.

Stevens, L.R., Ito, E., Schwalb, A., Wright Jr., H.E., 2006. Timing of atmospheric precipitation in the Zagros Mountains inferred from a multi-proxy record from Lake Mirabad, Iran. Quaternary Research 66, 494-500.

Stevens, L.R., Wright, H., Ito, E., 2001. Proposed changes in seasonality of climate during the Lateglacial and Holocene at Lake Zeribar, Iran. The Holocene 11, $747-755$.

Sun, D., Bloemendal, J., Rea, D., Vandenberghe, J., Jiang, F., An, Z., Su, R., 2002. Grain-size distribution function of polymodal sediments in hydraulic and aeolian environments, and numerical partitioning of the sedimentary components. Sedimentary Geology 152, 263-277.

Tate, G.P., 1910. Seistan: a memoir on the history, topography, ruins, and people of the country. In: Four Parts. Superintendent Government Printing.

Tosi, M., 1983. Prehistoric Sistan. IsMEO.

Tsoar, H., Pye, K., 1987. Dust transport and the question of desert loess formation. Sedimentology 34, 139-153.

Van Campo, E., 1986. Monsoon fluctuations in two 20,000-yr BP oxygen-isotope/ pollen records off southwest India. Quaternary Research 26, 376-388.

Van Campo, E., Cour, P., Sixuan, H., 1996. Holocene environmental changes in Bangong Co basin (Western Tibet). Part 2: the pollen record. Palaeogeography, Palaeoclimatology, Palaeoecology 120, 49-63.

Van Zeist, W., Wright, H.E., 1963. Preliminary pollen studies at Lake Zeribar, Zagros mountains, southwestern Iran. Science 140, 65-67.

Wasylikowa, K., Witkowski, A., Walanus, A., Hutorowicz, A., Alexandrowicz, S.W., Langer, J.J., 2006. Palaeolimnology of Lake Zeribar, Iran, and its climatic implications. Quaternary Research 66, 477-493.

Whitney, J.W., 2007. Geology, Water, and Wind in the Lower Helmand Basin, Southern Afghanistan. Scientific Investigations Report 2006-5182. USGS, Virginia, p. 40.

Wick, L., Lemcke, G., Sturm, M., 2003. Evidence of Lateglacial and Holocene climatic change and human impact in eastern Anatolia: high-resolution pollen, charcoal, isotopic and geochemical records from the laminated sediments of Lake Van, Turkey. The Holocene 13, 665-675.

Williams-Sether, T., 2008. Streamflow Characteristics of Streams in the Helmand Basin, Afghanistan. US Department of the Interior, US Geological Survey.

Yang, S., Ding, Z., 2004. Comparison of particle size characteristics of the tertiary 'red clay'and Pleistocene loess in the Chinese Loess Plateau: implications for origin and sources of the 'red clay'. Sedimentology 51, 77-93. 